\title{
Insight in Adhesion Protein Sialylation and Microgravity Dependent Cell Adhesion-An Omics Network Approach
}

\author{
Thomas J. Bauer $^{1}$, Erich Gombocz ${ }^{2}{ }^{\oplus}$, Markus Wehland ${ }^{1}{ }^{\circledR}$, Johann Bauer ${ }^{3, *}$, Manfred Infanger ${ }^{1}$ \\ and Daniela Grimm ${ }^{1,4,5}$ \\ 1 Clinic for Plastic, Aesthetic and Hand Surgery, Otto-von-Guericke-University Magdeburg, \\ D-39120 Magdeburg, Germany; thomas.bauer@med.ovgu.de (T.J.B.); \\ markus.wehland@med.ovgu.de (M.W.); manfred.infanger@med.ovgu.de (M.I.); dgg@biomed.au.dk (D.G.) \\ Melissa Informatics, 2550 Ninth Street, Suite 114, Berkeley, CA 94710, USA; egombocz@ix.netcom.com \\ Max Planck Institute of Biochemistry, D-82152 Martinsried, Germany \\ Department of Biomedicine, Aarhus University Hospital, DK-8000 Aarhus C, Denmark \\ 5 Department of Microgravity and Translational Regenerative Medicine, Otto von Guericke University, Pfälzer \\ Platz, 39106 Magdeburg, Germany \\ * Correspondence: jbauer@biochem.mpg.de; Tel.: +49-89-85783803
}

Received: 10 February 2020; Accepted: 2 March 2020; Published: 4 March 2020

\begin{abstract}
The adhesion behavior of human tissue cells changes in vitro, when gravity forces affecting these cells are modified. To understand the mechanisms underlying these changes, proteins involved in cell-cell or cell-extracellular matrix adhesion, their expression, accumulation, localization, and posttranslational modification (PTM) regarding changes during exposure to microgravity were investigated. As the sialylation of adhesion proteins is influencing cell adhesion on Earth in vitro and in vivo, we analyzed the sialylation of cell adhesion molecules detected by omics studies on cells, which change their adhesion behavior when exposed to microgravity. Using a knowledge graph created from experimental omics data and semantic searches across several reference databases, we studied the sialylation of adhesion proteins glycosylated at their extracellular domains with regards to its sensitivity to microgravity. This way, experimental omics data networked with the current knowledge about the binding of sialic acids to cell adhesion proteins, its regulation, and interactions in between those proteins provided insights into the mechanisms behind our experimental findings, suggesting that balancing the sialylation against the de-sialylation of the terminal ends of the adhesion proteins' glycans influences their binding activity. This sheds light on the transition from two- to three-dimensional growth observed in microgravity, mirroring cell migration and cancer metastasis in vivo.
\end{abstract}

Keywords: linked open database; graphical SPARQL; semantic knowledgebase; proteome; integrin; cadherin

\section{Introduction}

Many types of human tissue cells split into two populations when cultured under simulated or real microgravity conditions. One population continues to grow in a monolayer (AD cells). The other one detaches from the bottom of a culture flask and forms three-dimensional aggregates called multicellular spheroids (MCS) [1]. This in vitro process appears to mirror metastasis in vivo, which also includes cell detachment and re-aggregation [2-4]. In recent studies, we subjected thyroid and breast cancer cells and endothelial cells, which had been cultured for a few days on ground, in Space or on a Random Positioning Machine (RPM) simulating microgravity, to mass spectrometry or microarray gene 
analyses. These high throughput omics technologies unveiled thousands of proteins or genes [5-8], including gravity-sensitive cell adhesion proteins such as integrins, which form alpha-beta dimers $[9,10]$, cadherins [6,11,12], and other cell adhesion molecules [13-15] as well as CD44 [16], whose sensitivity to microgravity has repeatedly been described [17]. CD44 is a cell surface receptor that plays a role in cell-cell interactions, cell adhesion, and migration, helping the cells to sense and respond to changes in the tissue microenvironment $[18,19]$.

The omics technology revealed changes of expression and/or accumulation of adhesion proteins under microgravity in AD and MCS cells as compared to control cells cultured under $1 g$-conditions $[5,6]$. Hence, additional information was collected about microgravity-dependent posttranslational modifications [20], including phosphorylation [9,21], ubiquitination [22,23], or isgylation [6,24], and about the intracellular translocation of adhesion proteins [25,26].

Posttranslational modification (PTM) is accomplished by enzymes such as kinases, phosphatases, or ligases [20-24]. In some types of PTM, carbohydrates are bound to reactive oxygens (O-glycan) or nitrogens ( $\mathrm{N}$-glycan) of a protein's amino acid side chains [27]. In many cases, a monosaccharide coupled to an amino acid is extended towards the environment of a cell by a number of additional sugar monomers forming a chain, which may be branched or linear [28]. Carbohydrate units coupled directly to an amino acid can be determined by mass spectrometry [29]. The results of such analyses have been collected in overview databases such as the UniProt (https://www.uniprot.org/) or dbPTM databases (http://dbptm.mbc.edu.tw) [20]. However, very often this knowledge is not sufficient, because the biological effect of a protein-bound carbohydrate system is exerted by carbohydrate monomers located at the terminal end of a glycan system consisting of tens or even hundreds of carbohydrate monomers. This is true regarding the antigenicity of soluble or cell-bound proteins as well as regarding negative surface charges located at a cell surface and influencing the environment $[28,30]$. Both traits are often formed by sialic acids (SAs) that are located at the most distant end of a carbohydrate system bound to a protein [31]. Hence sialylation deserves further elucidation.

SA is a nine-carbon acidic monosaccharide [32], whose carboxyl group is dissociated at physiological $\mathrm{pH}[32,33]$ and generates a negative charge. SA is bound to the tip of glycan systems, if CMP-sialic acid is available [34]. This substance is built up along a well-known pathway with sialic acid synthase (NANS) as the key enzyme [35]. Linked to a CMP, SA is transported to its destination point, where it is transferred to the tip of an existing glycan structure [36]. In humans, the transfer is catalyzed by 20 different types of sialyltransferases [34,37]. Conversely, four types of human neuraminidases, also called sialidases, can catalyze removing SAs from existing carbohydrate systems [38,39].

SA molecules bound to proteins affect the half-life of many circulating glycoproteins and also influence the cell-cell communication, cell matrix interaction, and cell adhesion [40,41]. As microgravity has effects on cell adhesion [5,6] and also influences the sialylation activity of insect cells [42], we were interested to see whether microgravity influences the sialylation of human cells, affecting their adhesion behavior.

To address this question, we selected human adhesion proteins, which we found to play a role in experiments when cancer or endothelial cells changed their behavior during exposure to microgravity [5,6,25], and we used the Knowledge Explorer (KE) [43,44], which allows the enrichment of experimental data with knowledge from several fact and reference databases (Figure 1), if the names and related analysis results of the selected proteins were imported via their UniProt accession numbers into an initial resource description framework (RDF) to create a knowledge base (KB) through a combination of semantic protocol and RDF query language (SPARQL) searches across several databases and importing their results iteratively (Figure 1). The resulting knowledge base was then assessed in detail to evaluate the importance of our findings in context. This data revealed that the sialylation of adhesion proteins influences the adhesion cells' behavior. 

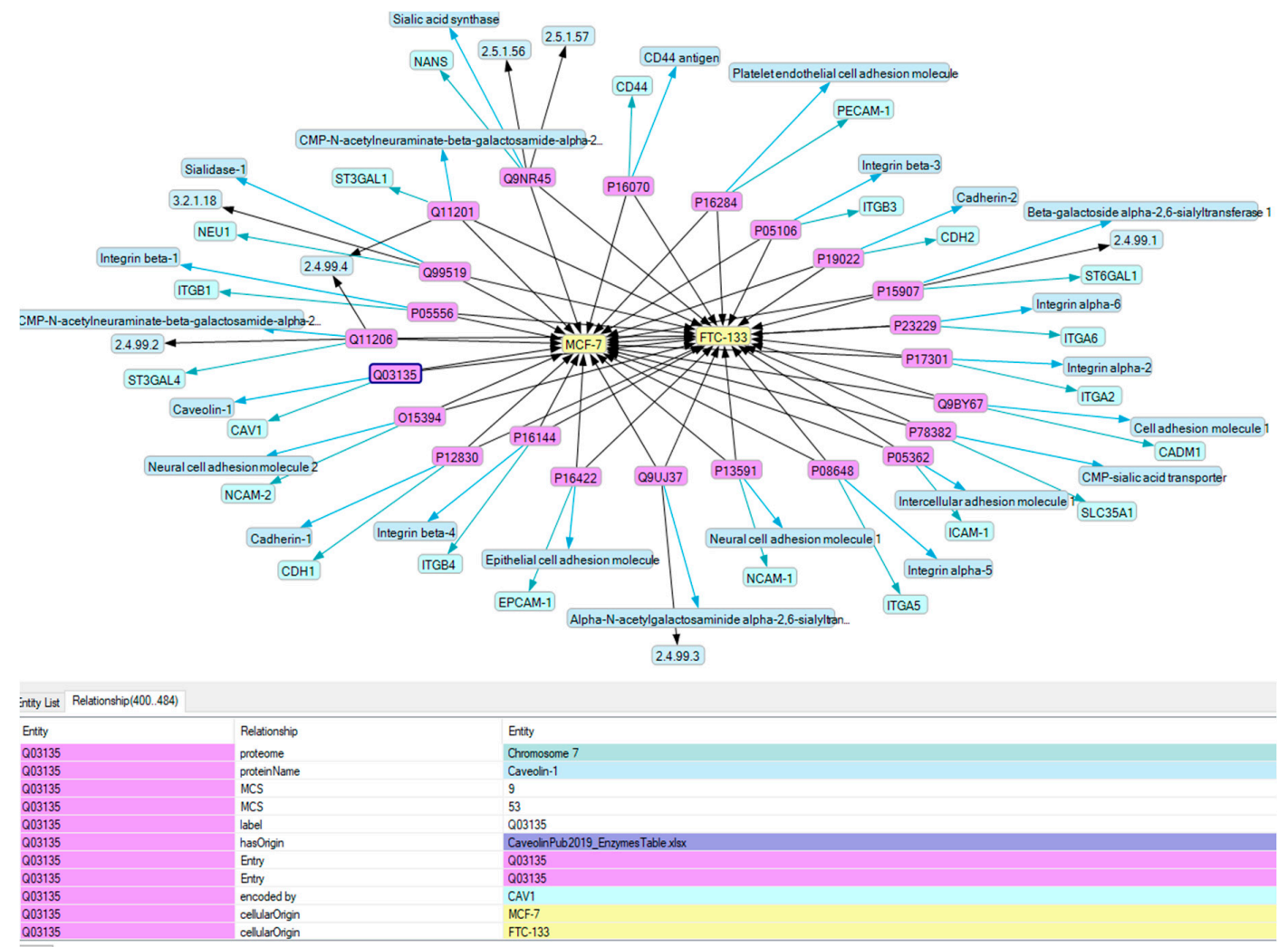

Figure 1. The initial semantic knowledge base used for the semantic enrichment of experimental data with current knowledge about the sialylation of adhesion proteins. The genes and names of human adhesion proteins found in omics experiments were loaded in a first step.

\section{Results and Discussion}

\subsection{Selected Cell Adhesion Proteins and Their Characterization Regarding Sialylation}

Aiming to get information about the function of SAs bound to the tips of the glycans, which cell adhesion proteins bear, we selected the proteins shown in Table 1. Information about them obtained by the earlier omics analysis and detected in the UniProt database was incorporated in a comprehensive KB. Using this KB to selectively retrieve references revealed more than 200 publications about the sialylation of these proteins. In addition, information about the identified proteins was collected regarding their structures, genes, sequences, and functions, as well as the types of cells producing them and the diseases where they play a role (Figure 2). Evaluating the references revealed 17 membrane-inserted proteins bearing glycans with SAs at their tips (Table 1). 


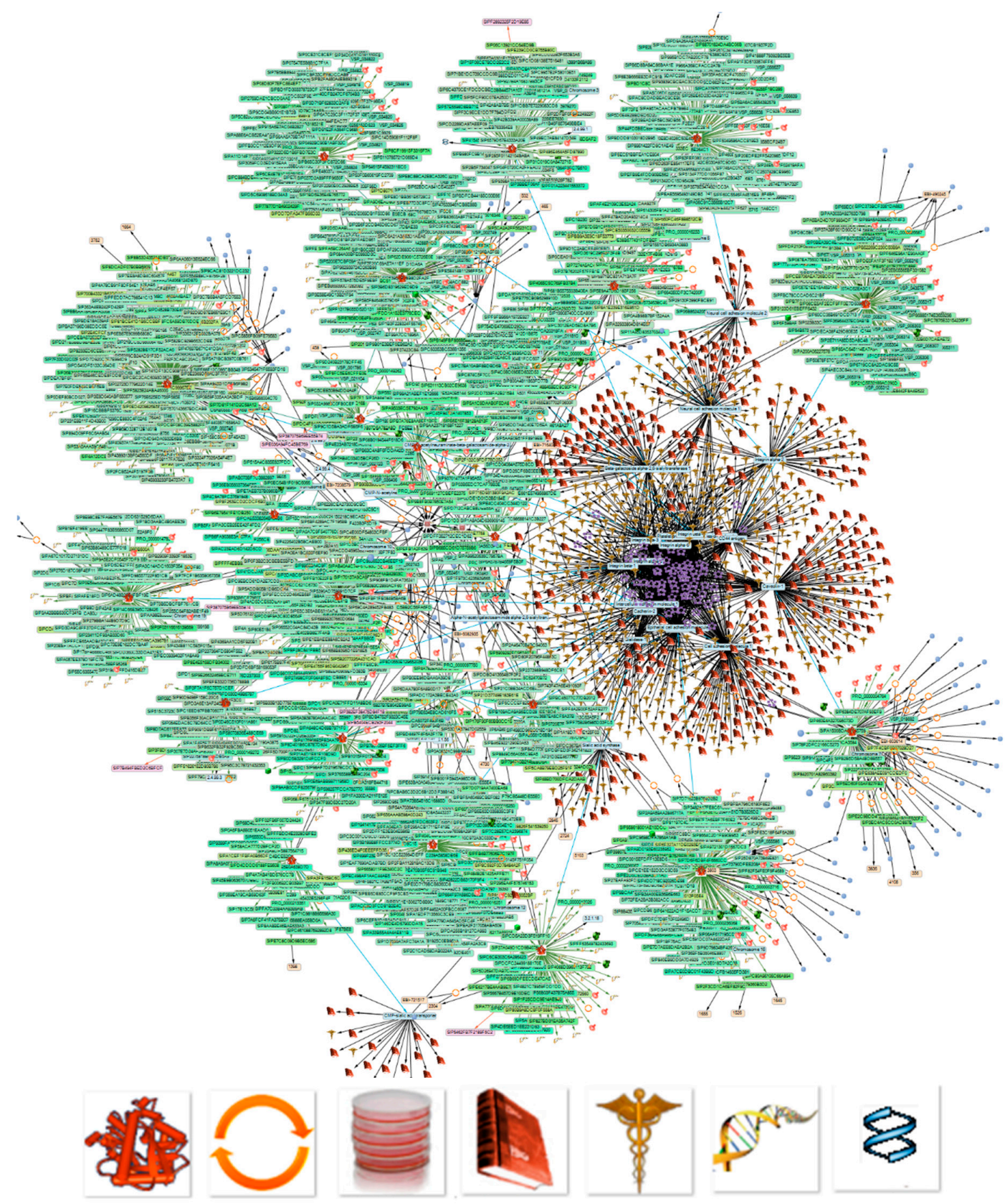

Figure 2. The results of KE-mediated searches for scientific information in reference and fact databases. The SwissProt accession numbers of the proteins shown in Table 1 were used to search for manuscripts about their sialylation in combination with further traits regarding their structures, genes, sequences, and functions. The various icons shown in the bottom line at a high magnification indicate the type of nodes (from left: protein structures, functions, cells producing the proteins, publications, diseases wherein the proteins play a role, genes, and sequences). The text within the picture becomes legible after magnification. 
Table 1. Proteins of MCF7 and FTC-133 cancer cells cultured under normal gravity ( $1 g$ ) or under simulated microgravity as adherent (AD) or as aggregated cells (MCS). The proteins were selected from recent proteome analyses [5,6] because their sialylation is described in the literature. UniProt accession numbers, genes, and label free quantitation values (LfQ) are indicated.

\begin{tabular}{lccccccc}
\hline \multirow{2}{*}{ Protein } & \multirow{2}{*}{ Gene } & \multicolumn{3}{c}{ MCF-7 } & \multicolumn{3}{c}{ FTC-133 } \\
\cline { 3 - 8 } & & $\mathbf{1 g}$ & AD & MCS & $\mathbf{1 g}$ & AD & MCS \\
\hline P19022 & CDH2 & 0 & 0 & 0 & 16.8 & 19.1 & 20.4 \\
P12830 & $*$ CDH1 & $40.8 \pm 3.5$ & $33.5 \pm 4.4$ & $19 \pm 4.5$ & 0 & 0 & 0 \\
P05362 & ICAM-1 & 0 & 0 & 0 & 1.9 & 0 & 1.26 \\
P13591 & NCAM-1 & 0 & 0 & 0 & 54.7 & 50.5 & 44.7 \\
O15394 & NCAM-2 & $2 \pm 0.5$ & $1.7 \pm 0.5$ & $2.1 \pm 0.5$ & 0 & 0 & 0 \\
P16422 & EPCAM & $4.85 \pm 1.9$ & $10.27 \pm 2.9$ & $3.61 \pm 1.9$ & 0 & 0 & 0 \\
Q9BY67 & $*$ CADM1 & $0.85 \pm 0.3$ & $0.5 \pm 0.4$ & 0 & 4.9 & 4.5 & 6.15 \\
Q9Y624 & JAMA & $2.55 \pm 0.6$ & $2 \pm 1.4$ & $3.4 \pm 3.9$ & 3.04 & 0 & 2.54 \\
P16070 & $*$ CD44 & $12.3 \pm 1.3$ & $3.8 \pm 0.8$ & $8.4 \pm 2.2$ & 31.8 & 71.4 & 63.6 \\
P05556 & $*$ ITGB1 & $15.1 \pm 1.7$ & $22.8 \pm 3.8$ & $16 \pm 2.7$ & 208 & 173 & 136 \\
P05106 & ITGB3 & 0 & 0 & 0 & 5.31 & 3.44 & 4.3 \\
P16144 & $*$ ITGB4 & $7.4 \pm 0.7$ & $6.1 \pm 1.4$ & $3.1 \pm 0.6$ & 0 & 0 & 0 \\
P06756 & $*$ ITGAV & $7.4 \pm 0.6$ & $10.1 \pm 2.5$ & $8.6 \pm 2.7$ & 108 & 106 & 87.5 \\
P17301 & $*$ ITGA2 & $4.5 \pm 0.3$ & $5.8 \pm 1.4$ & $4.2 \pm 0.4$ & 3.36 & 4.04 & 3.24 \\
P26006 & $*$ ITGA3 & $1.4 \pm 0.5$ & $1.3 \pm 0.9$ & $0.8 \pm 0.3$ & 113 & 75.2 & 59.2 \\
P08648 & $*$ ITGA5 & $0.95 \pm 0.2$ & $1.5 \pm 0.4$ & $2.88 \pm 0.7$ & 24.9 & 36.2 & 28.3 \\
P23229 & $*$ ITGA6 & $0.8 \pm 0.05$ & $0.47 \pm 0.05$ & $0.49 \pm 0.13$ & 8.03 & 10 & 9.9 \\
\hline
\end{tabular}

LfQ (label free quantitation) are scores given as $x^{*} 10^{8}$ [20]; Each LfQ value shown for the MCF-7 cells is an average value of the independent measurements of four equally prepared samples. Entities labeled by ${ }^{*}$ have already been mentioned in refs. [6] or [45]. They are included for comparison and completion purposes, because they are sialylated.

\subsubsection{Cadherins and Other Cell-Cell Adhesion Proteins}

CDH1 proteins were detected in MCF7 cells and CDH2 proteins in FTC-133 cells (Table 1). According to studies published in the literature, they occur in a sialylated and de-sialylated form: Human MCF7 breast cancer cells and pancreatic ductal adenocarcinoma cells (PDAC) have e-cadherins bearing glycans with terminal SAs [46-48]. Changes in the terminal SA units influence the e-cadherin's adhesion capability $[46,48]$. In addition, $\mathrm{N}$-cadherins expressed by various tumor cells bear glycans with terminal SAs [49-51]. Melanoma cells show sialylated N-cadherins, which have an influence on the metastatic capabilities of these tumor cells [50]. Removing the sialic acids from N-cadherin of HeLa cells by sialidase affects N-cadherin-ZO-1 association [49]. Furthermore, VE-cadherins of endothelial cells are sialylated. SAs of endothelial cells of human umbilical cord veins are suggested to play a role in VE-cadherin organization [52]. Their degree of sialylation is regulated by TNF-alpha [53]. We found VE-cadherin protein in EA.hy926 cells [7]. In these cells, the expression of CDH5 mRNA is reduced when they form tubular structures under microgravity [54]

CADM1 (cell adhesion molecule 1) is another membrane protein mediating homophilic cell-cell adhesion. We found CADM1 in MCF7 cells and with a higher concentration in FTC-133 cells (Table 1). Moreover, CADM1 is sialylated in A549 lung cancer cells [55]. Our proteome analysis also unveiled the junctional adhesion protein A (JAM-A) in MCF7 and FTC-133 cells. In both cell lines, a significant influence of microgravity was not detectable (Table 1). However, these proteins may bear N-glycans with terminal sialic acids, which regulate the cells' (CHO cells) adherence [56].

\subsubsection{Integrins}

In the MCF7 cell line, exposure to microgravity significantly decreased ITGB4 in MCS cells, while it increased ITGA5 in these cells as compared to $1 g$ control cells and AD cells, respectively (Table 1). Furthermore, ITGB1 was enhanced in AD cells as compared to $1 g$ control cells and MCS cells. 
In the literature, a considerable amount of information was found indicating that integrins bear SAs, which affect the adhesion capabilities of cells [57].

A $\beta 1$ integrin region, called the $\beta 1$ I-like domain, is important for ligand binding. This region carries N-glycans at three asparagine residues (Asn 192, Asn 249, and Asn 343). Their terminal galactose may or may not be elongated by $\alpha 2-6$ sialic acid [58]. In the desialylated form, binding to the ligand is stronger than in the sialylated one [59]. The effect of sialylation appears to be due to conformational changes of the integrin $\beta 1$ protein [58]. The conformational changes may be responsible for the following observations made on the in vivo behavior of various cells: HD3 colonocytes regulate their invasion and migration via the sialylation of their $\beta 1$-integrins [60]. Sialylated integrin $\beta 1$ of SW480 colon cancer cells supports cell binding to fibronectin and counteracts apoptosis by activating paxillin and AKT [61]. Human SW48 colon epithelial cells show 2-6 sialylation of the $\beta 1$ integrin. When enhanced quantities of $\alpha 2-6$ sialic acids were bound to the SW480 cells' $\beta 1$-integrin subunits, their aggressiveness was especially high [62]. In this case, the SA blocks the pro-apoptotic effects of secreted galectin 3 [63]. The sialyltransferase inhibitor Lith-O-Asp decreased the sialic acid modification of integrin $\beta 1$ in mice and inhibited the expression of phospho-focal adhesion kinase, phospho-paxillin, and the matrix metalloproteases MMP2 and MMP9 [64]. Another sialyltransferase inhibitor, AL10, reduces the sialylation of various integrin molecules, especially $\beta 1$ integrin, and attenuates the activation of the integrin downstream signaling mediator focal adhesion kinase [65].

The alteration of the sialylation of integrin- $\beta 1$ also influences its dimerization with $\alpha$-integrin subunits [58]. MDA-MB-231 cells bear sialylated integrin $\alpha 2 / \beta 1$. In these cells, changes of the degree of sialylation affect adhesion without alteration of integrin expression [66]. Moreover, C4-2B prostate cancer cells exhibit $\alpha 2 \beta 1$ integrins on their cell surface with sialylated $\alpha 2$ subunits. The linked sialic acid residues are required for the cell adhesion to collagen type I and are responsible for the interaction with the carbohydrate moiety of an asialylated ganglioside, which changes the integrin's activity [67]. Furthermore, pancreatic Capan- 1 cells bear sialylated $\alpha 2 \beta 1$ integrins on their surface. The content of SAs of the glycans of this protein influences cell adhesion and invasion of these cancer cells by enhancing FAK-tyr-397 phosphorylation [48].

Another integrin dimer detected on cancer cells is $\alpha 5 \beta 1$ - integrin. For this dimer, the structure of the integrin alpha linked sialylated glycan has already been identified [68]. $\alpha 5 \beta 1$-integrins are also expressed by melanoma cells [69]. In these cells, both integrin subunits are sialylated and influence the binding behavior of the dimer. Simultaneously, they influence the invasion capability of the cells, but do not affect the fibronectin binding of the isolated proteins. Hepatocellular carcinoma cells have $\alpha 5 \beta 1$-integrins, which bind to fibronectin. If fibronectin binding is not possible, they bind to galectin 1 , which induces apoptosis. If the $\alpha 5 \beta 1$-integrins are $\alpha 2,6$-sialylated, interaction with Gal-1 and anoikis is prevented [70]. If $\beta 1$ integrin of the $\alpha 5 \beta 1$-integrin dimers is sialylated, it regulates $\beta 1$ integrin subunit binding to fibronectin and induces cellular activities [71], while sialylation of the $\alpha 5$ subunit is important for the proper formation of the heterodimer [72]. After removal of sialic acids, $\alpha 5 \beta 1$-integrins of human melanoma G361 cells failed to bind to fibronectin-conjugated Sapharose [73]. Moreover, human T24 bladder cancer cells showed $\alpha 3 \beta 1$-integrins [74]. $\alpha 6 \beta 1$-integrin was found on endothelial cells mediating the cells' interaction with CD151 of platelets. The interaction promotes angiogenesis and depends on sialic acids because it is abolished by neuraminidase [75].

In addition to ITGB1, an influence of sialylation on ITGB4 and ITGB3 activities is described in the literature. The sialylation of cell surface integrin $\beta 4$ was down-regulated during the epithelial-mesenchymal transition of human keratinocyte HaCaT cells [31]. In colon cancer cells, NEU1 decreased the sialylation of integrin $\beta 4$ and suppressed cell adhesion in vitro [66,76]. When human WM793 primary melanoma cells gain metastatic competence, they show increased levels of sialylated $\alpha \mathrm{V} \beta 3$ integrins [77]. Cooperation of PECAM-VEGFR2-integrin $\beta 3$ is significantly reduced when integrin $\beta 3$ lacks 1,6-sialic acid [78]. 


\subsubsection{Cell Adhesion Molecules}

In the literature and fact databases, a number of studies were found indicating that the sialylation of cell adhesion molecules plays a decisive role, when endothelial cells, brain cells, or cancer cells break and reestablish external contacts. For example, the stabilization of ICAM-1 via sialylation decreases metastatic ability on colorectal cancer cells [79].

In our proteome studies, ICAM- 1 was detected in FTC-133 cells at a very low concentration, but not in MCF7 cells. In addition, we have found NCAM-1 in thyroid cancer cells and NCAM-2 in MCF7 cells. In neither case did we find a significant influence of microgravity on the accumulation of these proteins (Table 1). However, neural cellular adhesion molecules (NCAMs) show a peculiar sialylation pattern. In contrast to many other sialylated adhesion proteins, which have one or two terminal SAs at the tip of their glycans [80], NCams often have terminal carbohydrate polymers consisting of up to 100 SA monomers [81,82]. Polysialic acid is characteristic for developing neurons, but it is also expressed by glucagonomas [83]. Such terminal SA polymers modify NCAM and regulate cell adherence and cell-cell interaction [84,85]. In neuroblastoma cells, as well as in small cell lung cancer, it favors metastasis $[86,87]$. In chick embryonic brain cells, the partial and total desialylation of NCAMs regulates cell adhesion differently [88]. In MCF7 cells, polysialylation affects the adhesion of NCAM to the extracellular matrix [89]. Furthermore, polysialylated NCAM reduces E-cadherin-mediated cellular adhesion, facilitating the dissemination of tumor cells [90]. EpCAM (epithelial cell adhesion molecule) is another homophilic interaction molecule of epithelial cells. We detected this molecule in MCF7 cells. Chen et al. found that EpCAM is sialylated in MCF7 and that its degree of sialylation may be changed by drugs [91].

We found PeCAM in the membrane fractions of Ea.hy926 and microvascular endothelial cells [7]. Its electrophoretic behavior suggested a lower $\mathrm{pI}$, as indicated in databases. The difference may be explained as PeCAM occurs in sialylated and de-sialylated forms [92]. In endothelial cells, SA regulates the adhesion and downstream apoptotic signaling [93]. In human mesothelioma cells, a PECAM 1 was found that is bound to Asn- 25 and bears a terminal $\alpha 2,3$ sialic acid moiety. This negatively charged moiety forms an electrostatic bridge with the positively charged Lys-89, stabilizing the PECAM-1 homophilic binding interface [94]. Depending on the status of sialylation, PECAM-1 influences the process of angiogenesis in different ways [92,95].

\subsubsection{CD44 Antigen}

The CD44 antigen bears terminal SAs at the tips of its glycans [96]. If CD44 N-glycans bear terminal SAs, hyaluronan binding is blocked as competing intramolecular contacts of sialic acid with arginine side chains are formed [97]. The sialidase inhibitor 2-deoxy-2,3-dehydro-N-acetylneuraminic acid blocks the recognition of hyaluronic acid, showing that sialylation negatively regulates CD44 activity [98]. Activation of sialidase by TNFalpha via MAPK38 initiates binding of CD44 to hyaluronic acid [97]. In colorectal cancer, metastasis to the liver occurs more frequently when CD44 is expressed on the surface together with sialyl Lewis(a) antigens [99]. Matsubara et al. concluded from their study that the sialylation status of CD44 may be more important for binding to hyaluronic acid than its degree of expression [100].

\subsubsection{Interaction of Sialylated Proteins}

The 17 proteins shown in Table 1, as well as two endothelial cell proteins, were found sialylated in the studies, underlying the references found by KE searches. In order to show how the sialylation of these proteins could trigger the cell reactions described in the studies mentioned above, we performed an interaction study using the KB. Figure 3 shows the interaction partners of the membrane-inserted proteins selected. They include a number of proteins, SPP1, MSN, FAS, CAV2, RAC1, SRC, EGFR, TLN1, ACTN1, PXN, PLEC, PTK2 and KDR, which emerged in our earlier studies as important players in transducing the signals of cell adhesion to the cytoskeleton $[5,6,45,54,101,102]$. 


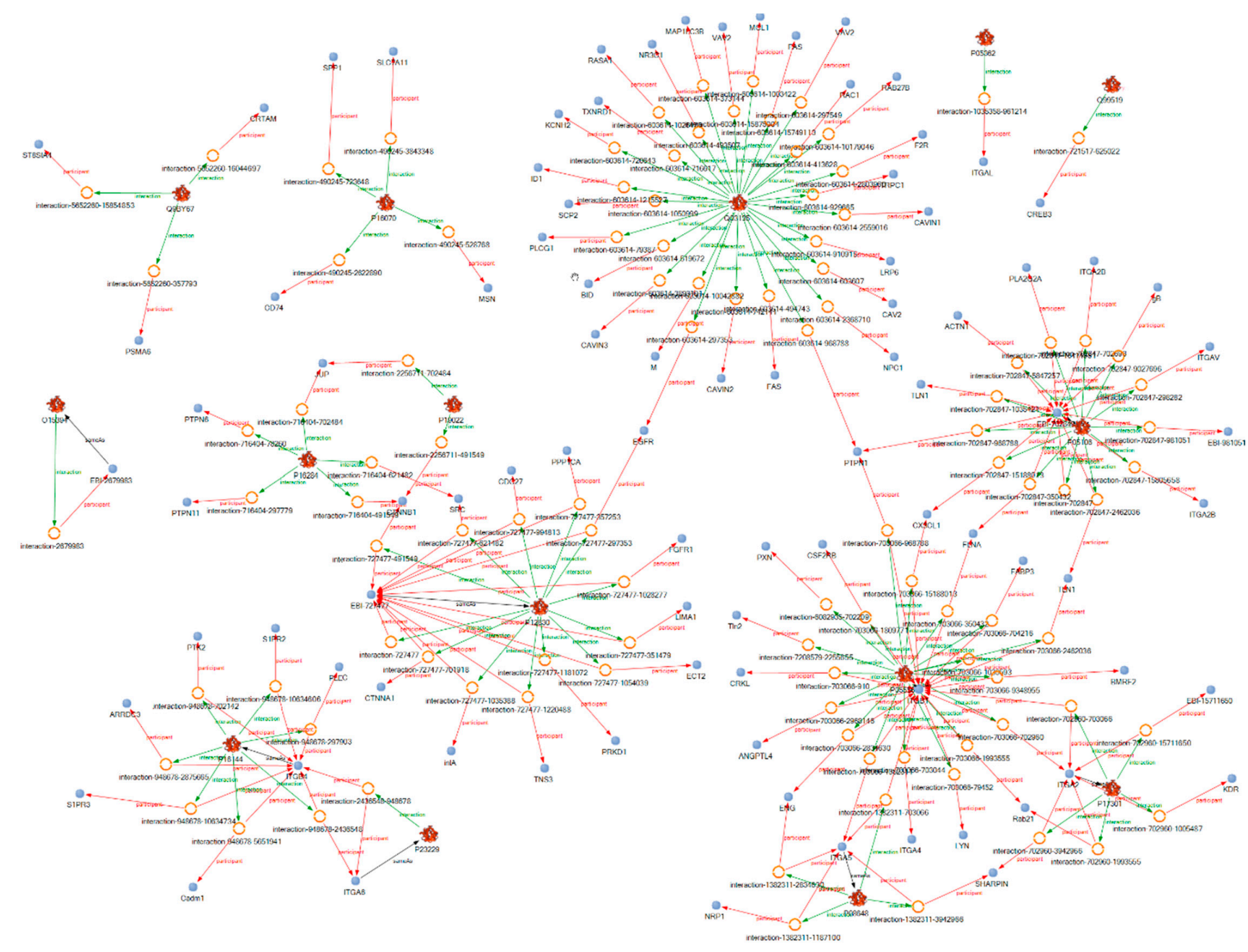

Figure 3. The interaction partners of the proteins shown in Table 1. The participants in the interaction were restricted to proteins playing a role in the signaling of cell adhesion. The text within the picture becomes legible after magnification. 


\subsection{Enzymes Responsible for the Status of Adhesion Proteins}

Some proteins shown in Table 1 are significantly changed in quantities (e.g., CDH1, EPCAM, CD44) but others (e.g., JAMA or various integrin subunits) not when exposed to microgravity. This suggests that besides the accumulation of sialylable proteins, their actual sialylation could play a role $[58,103]$. Taking the information described in Section 2.1 together, it appears evident that sialylation and de-sialylation occurs on equal proteins. From this observation, one may conclude that the amount of sialic acid transiently bound to a protein is regulated by an interplay of sialyltransferases and neuraminidases [104-106]. Our proteome analysis revealed NEU1 (Table 2). Its accumulation is more than 20-fold higher in FTC-133 cells than in MCF7 cells. In both cases, however, its concentration was higher in MCS cells than in AD cells found after incubation under simulated microgravity (Table 2).

We also detected NANS in MCF7 breast cancer and FTC-133 follicular thyroid cancer cells during recent proteome analyses. In MCF7 cells, much more NANS was found as compared to the FTC-133 cells. Exposure of the cells to microgravity slightly enhanced the NANS concentrations in both cell lines (Table 2).

Although the CMP-sialic acid transporter coded by the SLC35A1 gene emerged in the proteome analysis of MCF7 cells (Table 2), neither the literature nor a semantic analysis of the functional association of the proteins of Table 1 indicated a role of this transporter in the sialylation of adhesion proteins. In addition, three types of sialyltransfereases were detected (Table 2). However, ST3GAL1 (CMP-N-acetylneuraminate-beta-galactosamide-alpha-2,3-sialyltransferase 1; Q11201), ST3GAL4 (CMP-N-acetylneuraminate-beta-galactosamide-alpha-2,3-sialyltransferase 4; Q11206), and ST6GALNAc2 (Alpha-N-acetylgalactosaminide alpha-2,6-sialyltransferase 2; QUJ37) were found in MCF7 cells, while only ST3GAL4 emerged in the analysis of the FTC-133 cells (Table 2). These enzymes are mainly involved in the sialylation of mucins [107]. Still, recent publications described that ST3GAL1 contributes to the sialylation of integrin $\beta 1$ and CD44 [108] and that the silencing of ST3GAL4 impairs the Ccl5-triggered integrin activation of mouse myeloid cells [109].

Although sialyltransferase ST3GAL1 and ST3GAL4 were found in our proteome experiments, ST6GAL1 (Beta-galactoside alpha-2,6-sialyltransferase 1) is most often mentioned within the manuscripts retrieved for this study about sialylation of adhesion proteins [110]. As shown in Figure 4, it transfers sialic acid from CMP-sialic acid to galactose-containing acceptor substrates. ST6GAL1 is capable of binding sialic acids to the tips of 391 different glycan structures, (see: https://www.glygen.org/glycoprotein_search.html) which have a galactose at their terminal end.

Proteins sialylated by ST6GAL1 are integrin beta 1 [110-115] and integrin beta3 [78]. ST6Gal I links SA to integrin $\beta 1$ in $\alpha 2-6$ mode [116]. Furthermore, in lung cancer cells, A549 CADM1 is sialylated by ST6Gal1. The sialylation is triggered by miRNA-199a and initiates signals to ErbB2/Erbb3 [55]. ICAM-1 is stabilized via sialylation by ST6Gal1 on colorectal cancer cells. The stabilization decreases metastatic ability [79]. PeCAM, which we found in an earlier mass spectrometry analysis of Ea.hy926 and microvascular endothelial cells [7], undergoes changes in sialylation as it is sialylated by ST6Gal 1 and desialylated by NEU1 [92]. Hence, the literature suggests that ST6GAL1, according to the current knowledge, plays a very important role in the sialylation of adhesion proteins. This suggestion is supported by interaction analyses, as shown in Figure 5. 


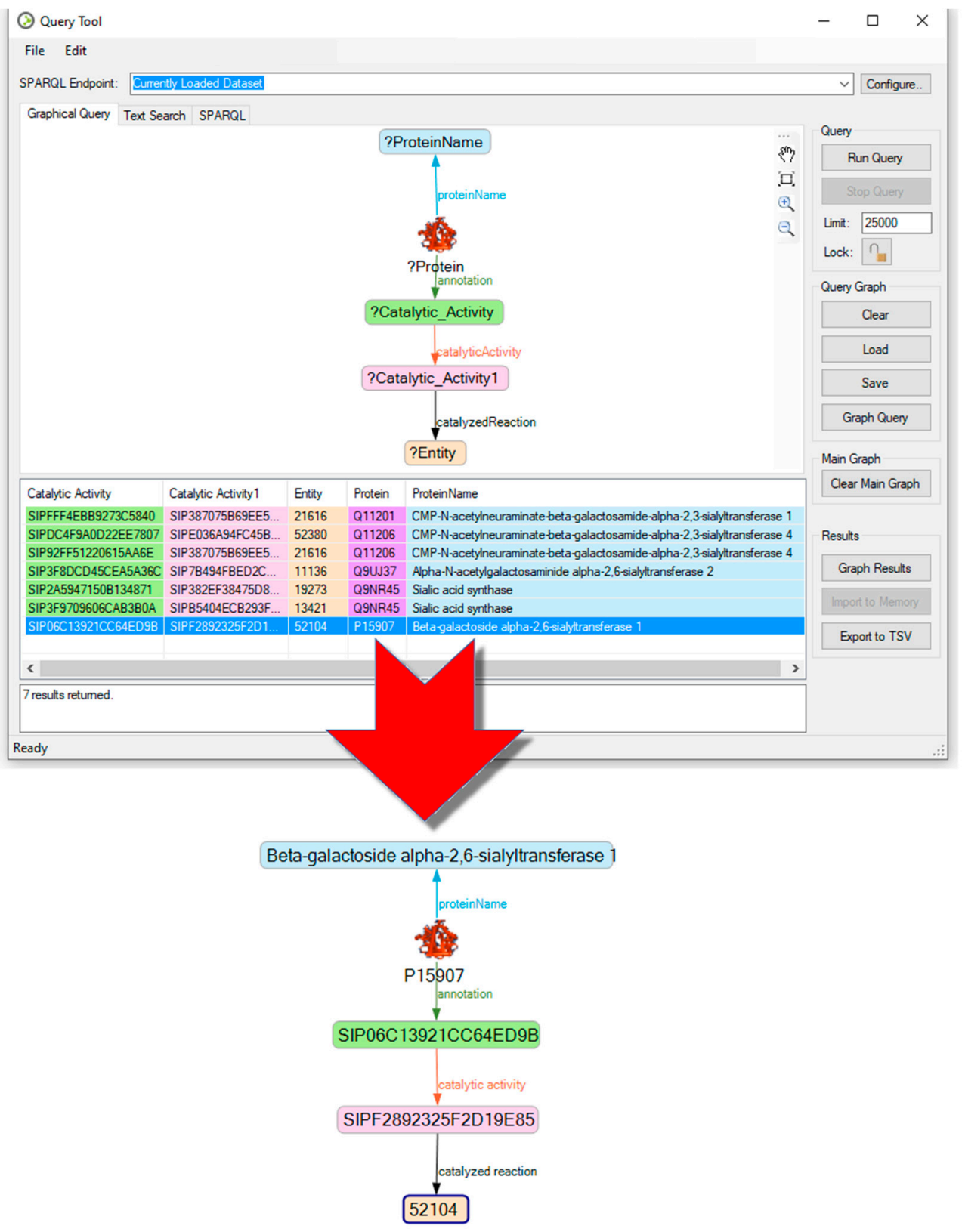

RHEA:52104

a beta-D-galactoside $+\mathrm{CMP}-\mathrm{N}$-acetyl-beta-neuraminate $=$ an $\mathrm{N}$-acetyl-alpha-neuraminyl-(2->6)-beta-D-galactosyl derivative $+\mathrm{CMP}+\mathrm{H}(+)$

Last modified: 2019-11-04. Chemically balanced: yes. Qualifiers: Class of reactions

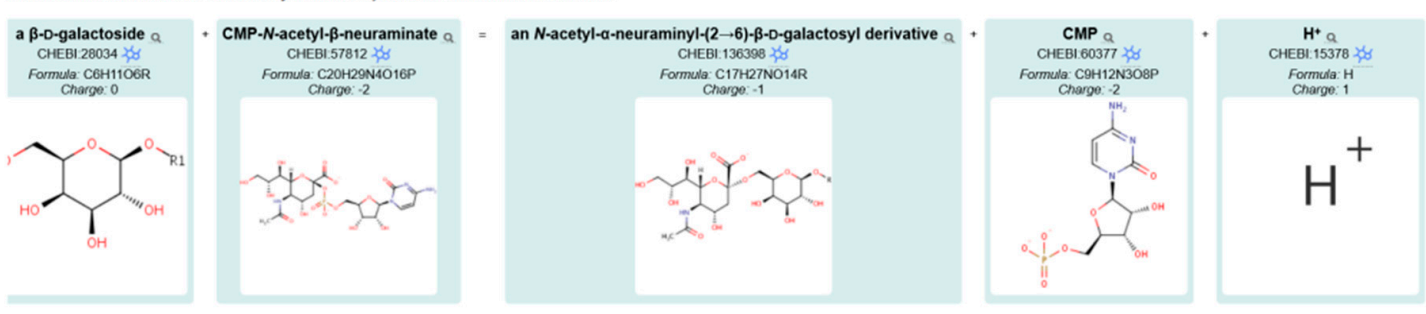

Figure 4. Graphical query for searching enzyme-catalyzed reactions catalyzed in Rhea (https://www.rheadb.org/reaction?id=?). The in dark blue highlighted result for P15907 in the query can be brought onto canvas, where the link from Rhea 52104 depicts the reaction catalyzed by ST6GAL1. SA is transferred from SA-CMP to a terminal galactose of an existing glycan (see: https://www.rhea-db.org/reaction?id=15907). 


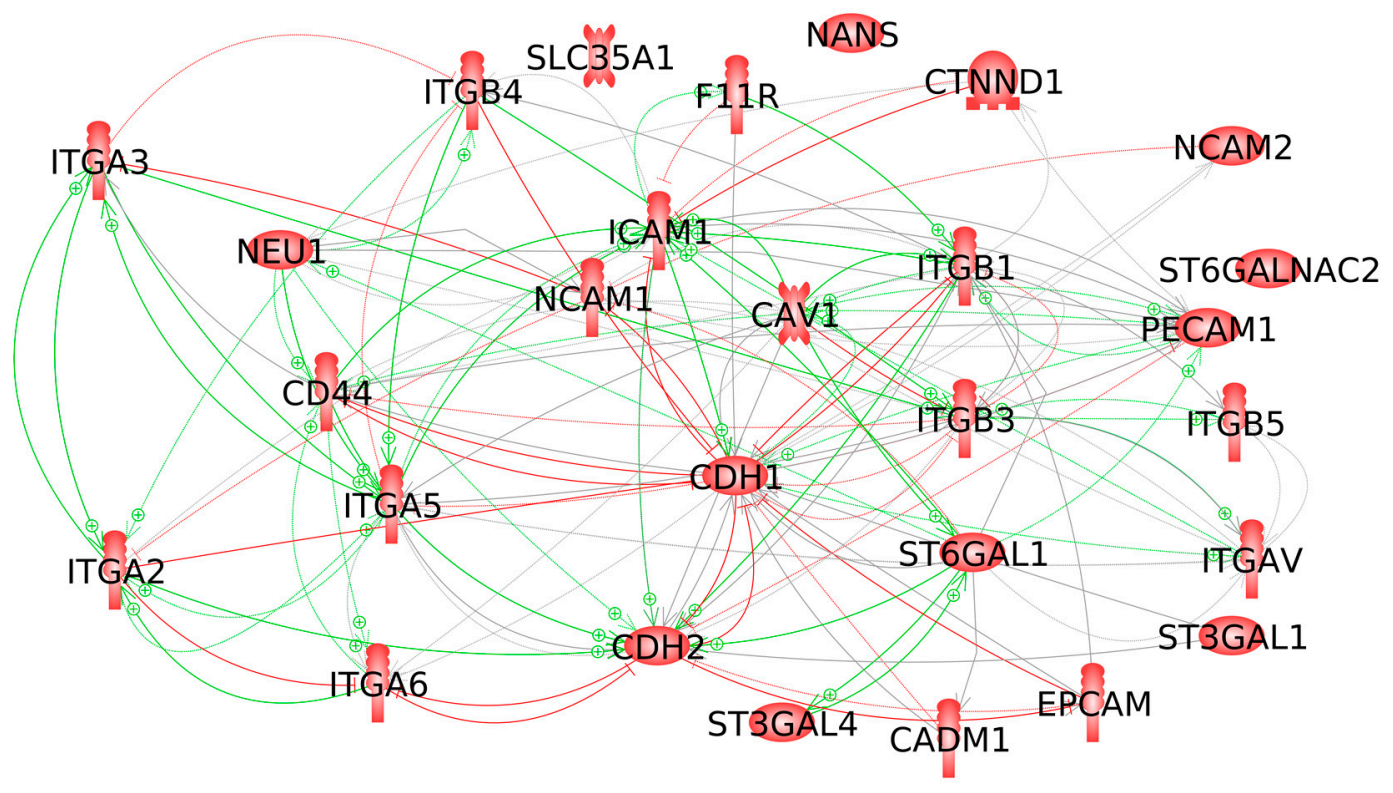

Figure 5. The mutual influence of selected entities at gene expression. Genes whose proteins were selected for a detail analysis by the network approach are shown. The green arrows indicate activating and the red arrows inhibiting effects. The grey lines indicate that interactions take place within the entities whose effects have not yet been clarified. The interaction network was built up using Elsevier Pathway Studio plus.

Table 2. Proteins of MCF7 and FTC-133 cancer cells cultured under normal gravity (1g) or under simulated microgravity as adherent (AD) or as aggregated cells (MCS). The proteins were selected from recent proteome analyses $[5,6]$ because they are involved in the sialylation of proteins. Uniprot accession numbers, genes, and label free quantitation values (LfQ) are indicated.

\begin{tabular}{cccccccc}
\hline \multirow{2}{*}{ Protein } & \multirow{2}{*}{ Gene } & \multicolumn{4}{c}{ MCF-7 } & \multicolumn{3}{c}{ FTC-133 } \\
\cline { 3 - 8 } & & $\mathbf{1 g}$ & AD & MCS & $\mathbf{1 g}$ & AD & MCS \\
\hline Q9NR45 & NANS & $69.5 \pm 4.7$ & $107 \pm 29$ & $93.2 \pm 14$ & 7.34 & 8.9 & 11.5 \\
P78382 & SLC35A1 & $0.29 \pm 0.2$ & 0 & $0.34 \pm 0.26$ & 0 & 0 & 0 \\
Q11201 & ST3GAL1 & $0.2 \pm 0.06$ & $1.05 \pm 0.5$ & $0.71 \pm 0.31$ & 0 & 0 & 0 \\
Q11206 & ST3GAL4 & 0 & $0.15 \pm 0.18$ & $0.33 \pm 0.39$ & 0.53 & 0 & 0 \\
Q9UJ37 & ST6GALNac2 & $0.18 \pm 0.08$ & 0 & $0.12 \pm 0.03$ & 0 & 0 & 0 \\
Q99519 & NEU1 & $0.97 \pm 0.3$ & $0.24 \pm 0.36$ & $0.78 \pm 0.15$ & 23.5 & 28.7 & 38.2 \\
O60716 & * CTNND1 & $39.5 \pm 1.5$ & $39.4 \pm 8.9$ & $19.3 \pm 4.5$ & 125 & 103 & 82.6 \\
Q03135 & $*$ CAV1 & $13.2 \pm 1.7$ & $3.34 \pm 0.43$ & $8.66 \pm 1.6$ & 64.7 & 92.5 & 53.5 \\
\hline P15907 & ST6GAL1 & 0 & 0 & 0 & 0 & 0 & 0 \\
\hline
\end{tabular}

LfQ (label free quantitation) are scores given as $x^{*} 10^{8}$ [20]; Each LfQ value shown for the MCF-7 cells is an average value of the independent measurements of four equally prepared samples [6]. Entities labeled by * have already been mentioned in ref. [6] or [45]. They are included for comparison and completion purposes because they influence the sialylation of adhesion proteins.

\subsubsection{Regulation of Quantities}

As shown above, the status of the sialylation of adhesion proteins depends on the interplay of active sialyltransferases and neuraminidases. In vivo, this interplay can be affected by growth factors, drugs and other physiological components $[53,64,65,76,95,115,116]$. The expression of neuraminidases is affected by current physiological and pathological conditions $[117,118]$ and has, e.g., an influence on cell apoptosis [119]. Sialyltransferase activity can be changed by growth factors [120,121], oncogenes [60,122], or microRNAs [123] within a given type of cells.

In addition, the entities selected for this study have a considerable mutual influence on a gene expression level. Figure 5 shows that ST6GAL1 and NEU 1 not only sialylate or desialylate target glycans, 
but also influence the expression of the proteins bearing the SAs. The most interesting mRNAs of ST6GAL1 and of ST3GAL4 are up-regulated together [124], and the regulation of ST6GAL1 and CDH2 is interconnected [125]. Furthermore, sialidase treatment of human lung epithelial cells influences the expression of integrin $\alpha 5$ [126]. In FTC-133 and MCF-7 cells, the concentration of ST6GAL1 protein was obviously below the detection threshold of the applied mass spectroscopy technique. However, a microgravity-dependent regulation of its gene became evident when FTC-133 thyroid cells returned from the Shenzhou 8 Space flight were investigated [8]. In this experiment, the microarray gene analysis revealed a great number of genes which were more than two-fold up- or down-regulated in FTC-133 cells returning from the Shenzhou-8 spaceflight. The ST6Gal 1 gene was amongst them. Its expression was 9.38-fold down-regulated in AD cells and 8.12-fold in MCS cells. Therefore, one may conclude that microgravity can influence the sialylation of adhesion proteins via the regulation of the mRNA expression of ST6GAL1.

\subsubsection{Regulation of Activities}

In mouse hepatocarcinoma cells, caveolin-1 (CAV1) favors the sialylation of the $\alpha 5$ subunit promoting $\alpha 5 \beta 1$ integrin-dependent cell adhesion via enhancing FAK-mediated signaling [127]. Nonetheless, CAV1 can also support the activities of sialidase [128]. Thus, the expression and accumulation of caveolin-1 in AD cells (cells remaining adherent during exposure to microgravity) is most interesting [129-131], as AD cells of the FTC-133 cell line show enhanced CAV-1 [130], while AD cells of the MCF7 cell line show a reduced CAV1 (Table 2). Moreover, catenin delta 1 can also play a role. It is abundantly present in MCF7 and FTC-133 cells. However, less of this protein was detected in MCS cells formed under microgravity as compared to AD and $1 g$ control cells (Table 2). When endothelial cells achieve confluence, catenin delta 1 binds sialidase to PECAM-1 (CD31) to desialylate its glycan [95]. This suggests that not only do the quantities of neuraminidases and sialyltransferases decide whether sialylation or desialylation is favored, but so do their location and the kind of membrane association, respectively.

\subsection{Biochemical and Biophysical Effects of SAs Present on Extracellular Domains of Surface Proteins}

Many effects on cell behavior have been observed when the sialylation of adhesion proteins changed in vivo and in vitro. But little is known about the links between the sugar moieties bound to the tips of extracellular glycan of adhesion molecules and the effects exerted by these negatively charged molecules. Some clues can be derived from the literature, pointing to the possibilities that the conformation of the proteins, to which the sialic acid is bound, is changed [58]. A change of the conformation has an influence on the binding to extracellular matrix proteins or to extracellular domains of surface proteins of other cells. It could also give different signals to the cell interior with direction towards the cell nucleus [45].

It remains of interest whether the electrostatic units generated by the negative charges of the sialic acid have an effect under in vivo conditions when cells are embedded in a tissue and are surrounded by extracellular matrix. Until now, electrostatic units firmly bound to cell surfaces could be observed and quantitatively determined when singularized tissue cells were placed in an electric field of direct current $[132,133]$. It is known that the electrophoretic behavior of the cells depends on the amount of sialic acids bound to the cell surface [134], and similarities between the behavior of cells in an electric field and on an RPM have recently been reviewed [135]. In both cases, adhesion proteins played a major role.

\section{Materials and Methods}

\subsection{Biological Experiments}

\subsubsection{Cancer Cell Proteins}

The proteins were obtained by mass spectrometry from FTC-133 human follicular thyroid carcinoma cells and from MCF7 human breast adenocarcinoma cells according to protocols described 
in $[5,6]$. Prior to analysis, both types of cells had been grown either within a monolayer under normal $1 g$ laboratory conditions or exposed to an RPM, where one part remained adherent (AD cells), while the other one formed three-dimensional aggregates (MCS cells). Monolayer cells cultured under $1 g$, AD cells, and MCS cells were harvested and pelleted in separate samples. Each sample was subjected to a proteome analysis. In total, 12 different cell samples, i.e., four per incubation condition, were analyzed to determine as many proteins as possible of the MCF7 cells; and five pellets were investigated to identify proteins of the FTC-133 cells.

Mass spectrometry was performed, as described earlier in detail $[5,6]$. Shortly, cells were lysed. Their proteins were digested overnight at $37^{\circ} \mathrm{C}$ with endoproteinase Lys- $\mathrm{C}$ (Wako Chemicals $\mathrm{GmbH}$, Neuss, Germany). The digested peptides were purified and then separated using the Thermo easy n-LC 1000 system (Thermo Scientific, Waltham, MA, USA). The peptides eluting from the column were directly sprayed into a Q Exactive HF mass spectrometer (Thermo Scientific, Waltham, MA, USA) via a nano-electrospray ionization source (Thermo Scientific, Waltham, MA, USA) [136,137]. The mass spectrometer was operated in a data-dependent top 15 mode. Survey scans and fragmentation scans were acquired at resolutions of 60,000 and 15,000 respectively $(m / z=200)$. Fragmentation was performed on precursors isolated within a window of $1.4 \mathrm{~m} / \mathrm{z}$ with a normalized collision energy setting of 27 .

Raw data from the mass spectrometer were processed using MaxQuant computational proteomics platform version 1.5.2.22 (Computational Systems Biochemistry, Max-Planck-Gesellschaft, Munich, Germany) [138] using the standard parameters. At least 5900 different proteins were identified in five FTC-133 cell samples [5], and 6500 different proteins were found in 12 MCF-7 cell samples [6]. These proteins formed the base for applying the MaxLfQ algorithm to determine the relative protein concentration by delayed normalization, as explained by Cox et al. in detail [139]. This label-free quantification technology is based on the assumption that a majority of proteins exists which does not change between the samples of a cell line.

\subsubsection{Endothelial Cell Proteins}

The proteins were obtained by mass spectrometry from EA-hy926 and dermal microvascular endothelial cells according to protocols described in [7]. Shortly, both types of cells had been grown either within a monolayer under normal $1 g$ laboratory conditions or exposed to an RPM, where one part remained adherent (AD cells) while the other one formed three-dimensional tubular aggregates (tube cells). Monolayer cells cultured under $1 g$, AD cells, and tube cells were harvested and pelleted in separate samples. Each cell sample was lysed by sonication. Then, soluble proteins and remaining cell fragments were separated by centrifugation. Both fractions were subjected to free flow electrophoretic separation. The resulting fractions were subjected to SDS page and stained. Bands of interest were cut out and forwarded to mass spectrometry, which was performed using an UltiMate 3000 nano-LC system (Dionex, Idstein, Germany) coupled to an ESI-linear ion trap (LTQ XL, Thermo Electron, Karlsruhe, Germany), as described in [140].

\subsubsection{Cancer Cell Genes}

The differential gene expression on FTC-133 thyroid cancer cells was analyzed, after the cells had been cultured in space for 10 days during the Shenzhou- 8 space mission. For the gene arrays, $1 g$ control cells and both AD cells and MCSs returning from the 10-day lasting spaceflight were collected separately for RNA extraction. Each time, four independent RNA preparations from the resulting three different conditions were processed and hybridized with the Illumina HumanWG-6_V2_0_R3_11223189_A array (Illumina, Inc., San Diego, CA, USA), as described in [8].

\subsection{Creation of A Semantic Network}

To create a semantic network, harmonize the content from multiple resources, and allow for graphical querying and reasoning, experimental data were imported to establish an initial 
resource description framework (RDF) knowledge base using KE (Melissa Informatics, Berkeley, CA, USA - former IO Informatics). This tool allows one to create, merge, and/or align semantic knowledge bases (SKB) in the form of RDF serializations as files or in backend databases and to configure and connect them to public semantic protocol and RDF query language (SPARQL) endpoints for query and import [20,43-45]. Its import functions provide abilities for nomenclature alignment, to set or automate reification IDs for blank nodes, and to establish mapping for spreadsheets or XML datasets. After importing the experimental proteomics data, an initial partial ontology imported from UniProt (in XML-RDF format) was transformed into a core RDF representation. A thesaurus manager was used to harmonize synonyms and avoid duplication during the import process.

UniProt content was queried for each of the proteins using its SPARQL endpoint $[43,44,141]$. This added functional, cellular location, chromosomal, and interaction properties to augment the information on the enzymes and reported protein functions [45,142]. The information collected was used to retrieve content from the Entréz resources OMIM, Protein, PubMed, and Biosystems (Figure 6), as well as from dbPTM, GlyGen, Rhea, and Atlas of Genetics and Cytogenetics $[20,143]$ by means of graphical queries and their result imports (Figure 4).

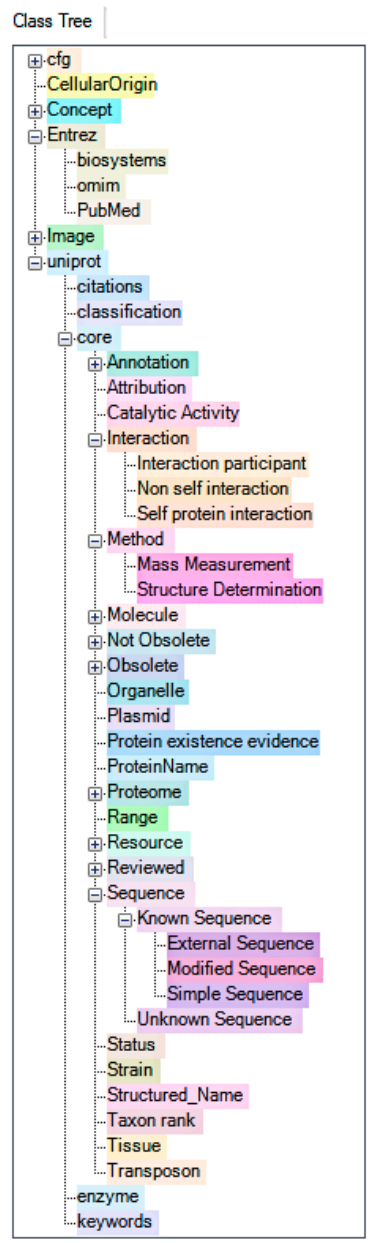

\begin{tabular}{|c|c|c|c|}
\hline type & organism & begin & URLConstructorParameter \\
\hline label & isolatedFrom & end & EntrezID \\
\hline comment & encoded by & position & hasOrigin \\
\hline versionlnfo & annotation & reference & PubDate \\
\hline isDefinedBy & existence & substitution & EPubDate \\
\hline seeAlso & classified with & mass & Source \\
\hline domain & sequence & crc64Checksum & LastAuthor \\
\hline range & potentialSequence & value & Title \\
\hline subPropertyOf & attribution & creator & Volume \\
\hline first & proteome & manual & Issue \\
\hline rest & title & evidence & Pages \\
\hline unionof & author & source & NlmUniquelD \\
\hline onProperty & exactMatch & based on & ISSN \\
\hline onClass & primaryTopic Of & modification & ESSN \\
\hline qualifiedCardinality & date & interaction & RecordStatus \\
\hline maxQualifiedCardinality & name & submittedTo & PubStatus \\
\hline intersection Of & volume & ecName & DOI \\
\hline inverseOf & pages & closeMatch & HasAbstract \\
\hline oneOf & scope & orientation & PmcRefCount \\
\hline subClass Of & context & disease & FullJoumalName \\
\hline deprecated & identfifier & related & ELocationID \\
\hline cardinality & group & xeno & so \\
\hline someValuesFrom & database & experiments & hasEntrezltem \\
\hline disjointWith & located on & participant & haslmage \\
\hline allValuesFrom & translatedTo & sameAs & haslmagefile \\
\hline maxCardinality & transcribedFrom & precursor & \\
\hline hasValue & signatureSequenceMatch & method & publishedOn \\
\hline equivalentClass & translatedFrom & resolution & pmid \\
\hline minCardinality & full Name & chainSequenceMapping & imgCaption \\
\hline onDataRange & shortName & chain & hasColorSpace \\
\hline distinctMembers & predicate & sequenceDiscrepancy & hasPixelDepth \\
\hline reviewed & subject & component & haslmageCopyright \\
\hline created & object & cdAntigenName & doi \\
\hline modfied & prefLabel & hasOrigin & source \\
\hline version & attLabel & Entry & ModifyDate \\
\hline Mnemonic & catalytic activity & proteinName & feedbackur \\
\hline oldMnemonic & catalyzed reaction & cellularOrigin & sourceurt \\
\hline replaces & enzyme class & و او1 & imports \\
\hline citation & locatedln & $A D$ & Oid \\
\hline conflictingSequence & cellularComponent & MCS & Locus \\
\hline recommendedName & topology & originates & Att Titles \\
\hline altemativeName & range & enratum & glycan_detail \\
\hline enzyme & beqin & URLConstructor & \\
\hline
\end{tabular}

Figure 6. The dynamic generated applications ontology and relationships in the KE Knowledge Graph. Left panel: class tree with partially expanded subclasses; right panel: relationships between class entities. The colorization of the classes allows for easy distinction of their instances in the knowledge graph. All Entrez databases are displayed in light brown shades. Subclass colors are shades of the color of the corresponding root class. 


\subsection{Interaction Analysis}

To investigate and visualize the interactions between the selected proteins and genes, we inputted relevant UniProtKB entry numbers into the Pathway Studio plus software (Elsevier Research Solutions, Amsterdam, the Netherlands). The identified genes were analyzed according to their mutual regulation [54].

\subsection{Statistical Evaluation}

The Man-Whitney-U-Test was used to compare the LfQ values of MCF7 cells harvested after incubation either at $1 g$ or at a microgravity condition. Data is presented as the mean \pm standard deviation (SD) with a significance level of $p<0.05$.

\section{Conclusions}

The omics network approach described in this paper shows how to gain advantage from combining the results of three different experiments with each other and with the knowledge described in the literature, while focusing on those parts of the data which are related to the topic of cell adhesion. The data experimentally obtained on the accumulation of adhesion proteins in three different types of cells by mass spectrometry [5-7] and by microarray studies on mRNA expression [8] were incorporated in a common network with the current knowledge on sialylation. This semantic network generation was made possible with the help of KE, an advanced information retrieval tool for generating and interrogating complex knowledge graphs. Taking all this information together, we were able to conclude that microgravity influences the sialylation-dependent activities of adhesion proteins on three levels: (i) expression and accumulation of adhesion proteins, (ii) expression and accumulation of enzymes sialylating or de-sialylating glycan systems bound to adhesion proteins, and (iii) expression, accumulation, and localization of scaffold proteins supporting the activity of the enzymes. The gained knowledge suggests that the process of linking cells to each other or to the ECM under microgravity includes the sialylation of extracellular domains of adhesion proteins.

Hence, it appears worthwhile to emphasize the sialylation of adhesion proteins in future space research, as the related transition from a two- to a three-dimensional growth appears to mirror some steps of cell migration and cancer cell metastasis in vivo where ST6GAL1 plays a role [144].

Author Contributions: Conceptualization, E.G. and J.B.; Cell culturing, D.G.; Gene arrays, M.W.; Software and data evaluation J.B., E.G., T.J.B.; Validation, J.B., D.G., M.I.; Resources, M.I.; Writing-Original draft preparation, E.G., T.J.B., D.G., J.B.; funding acquisition, D.G. and M.I. All authors have read and agree to the published version of the manuscript.

Funding: This research was funded by BMWi/DLR (Bundesministerium für Wirtschaft und Energie, und Deutsches Zentrum für Luft- und Raumfahrt) grants 50WB1524 and 50WB1924 (DG).

Acknowledgments: We thank Nagarjuna Nagaraj of the biochemistry core facility at the Max-Planck Institute of Biochemistry for performing proteomic sample preparation and measurements. We would also like to thank Jayashree Sahana, Department of Biomedicine, Aarhus University, Aarhus, Denmark, for culturing the cells and performing the RPM experiments for mass spectrometry.

Conflicts of Interest: The authors declare no conflict of interest.

\section{Abbreviations}

ST3GAL1 CMP-N-acetylneuraminate-beta-galactosamide-alpha-2,3-sialyltransferase 1

ST3GAL4 CMP-N-acetylneuraminate-beta-galactosamide-alpha-2,3-sialyltransferase 4

ST6GALNac2 Alpha-N-acetylgalactosaminide alpha-2,6-sialyltransferase 2

ST6GAL1 Beta-galactoside alpha-2,6-sialyltransferase 1

SLC35A1 CMP-sialic acid transporter

NEU1 Sialidase-1

SA Sialic acid

NANS Sialic acid synthase 


$\begin{array}{ll}\text { CAV1 } & \text { Caveolin-1 } \\ \text { CDH2 } & \text { Cadherin-2 } \\ \text { CDH1 } & \text { Cadherin-1 } \\ \text { CADM1 } & \text { Cell adhesion molecule 1 } \\ \text { ICAM-1 } & \text { Intercellular adhesion molecule 1 } \\ \text { NCAM-1 } & \text { Neural cell adhesion molecule 1 } \\ \text { NCAM-2 } & \text { Neural cell adhesion molecule 2 } \\ \text { PECAM-1 } & \text { Platelet endothelial cell adhesion molecule 1 } \\ \text { EPCAM } & \text { Epithelial cell adhesion molecule } \\ \text { JAMA } & \text { Junctional adhesion molecule A } \\ \text { CTNND1 } & \text { Catenin delta 1 } \\ \text { CD44 } & \text { CD44 antigen } \\ \text { ITGB1 } & \text { Integrin beta-1 } \\ \text { ITGB3 } & \text { Integrin beta-3 } \\ \text { ITGB4 } & \text { Integrin beta-4 } \\ \text { ITGA2 } & \text { Integrin alpha-2 } \\ \text { ITGA5 } & \text { Integrin alpha-5 } \\ \text { ITGA6 } & \text { Integrin alpha-6 } \\ \text { RDF } & \text { Resource description framework (RDF) } \\ \text { SPARQL } & \text { Semantic protocol and RDF query language (SPARQL) } \\ \text { SKB } & \text { Semantic knowledge base } \\ \text { LfQ } & \text { Label free quantification } \\ \text { RPM } & \text { Random positioning machine } \\ \text { AD cells } & \text { Cells growing adherently on the RPM } \\ \text { MCS cells } & \text { Cells growing within multicellular spheroids on the RPM } \\ \end{array}$

\section{References}

1. Aleshcheva, G.; Bauer, J.; Hemmersbach, R.; Slumstrup, L.; Wehland, M.; Infanger, M.; Grimm, D. Scaffold-free Tissue Formation Under Real and Simulated Microgravity Conditions. Basic Clin. Pharmacol. Toxicol. 2016, 119, 26-33. [CrossRef] [PubMed]

2. Buravkova, L.B.; Grigorieva, O.V.; Konstantinova, N.A.; Guershovich, Y.G.; Guershovich, P.M. Cell-to-cell interactions in microgravity experiments in vitro. Aviakosmicheskaya i Ekologicheskaya Meditsina 2013, 47, $68-72$.

3. Meyers, V.E.; Zayzafoon, M.; Gonda, S.R.; Gathings, W.E.; McDonald, J.M. Modeled microgravity disrupts collagen I/integrin signaling during osteoblastic differentiation of human mesenchymal stem cells. J. Cell Biochem. 2004, 93, 697-707. [CrossRef] [PubMed]

4. Krüger, M.; Melnik, D.; Kopp, S.; Buken, C.; Sahana, J.; Bauer, J.; Wehland, M.; Hemmersbach, R.; Corydon, T.J.; Infanger, M.; et al. Fighting thyroid cancer with microgravity research. Int. J. Mol. Sci. 2019, 20, 2553. [CrossRef] [PubMed]

5. Bauer, J.; Kopp, S.; Schlagberger, E.M.; Grosse, J.; Sahana, J.; Riwaldt, S.; Wehland, M.; Luetzenberg, R.; Infanger, M.; Grimm, D. Proteome analysis of human follicular thyroid cancer cells exposed to the random positioning machine. Int. J. Mol. Sci. 2017, 18, 546. [CrossRef]

6. Sahana, J.; Nassef, M.Z.; Wehland, M.; Kopp, S.; Krüger, M.; Corydon, T.J.; Infanger, M.; Bauer, J.; Grimm, D. Decreased E-Cadherin in MCF7 Human Breast Cancer Cells Forming Multicellular Spheroids Exposed to Simulated Microgravity. Proteomics 2018, 18, 1800015.

7. Ma, X.; Sickmann, A.; Pietsch, J.; Wildgruber, R.; Weber, G.; Infanger, M.; Bauer, J.; Grimm, D. Proteomic differences between microvascular endothelial cells and the EA.hy926 cell line forming three-dimensional structures. Proteomics 2014, 14, 689-698. [CrossRef]

8. Ma, X.; Pietsch, J.; Wehland, M.; Schulz, H.; Saar, K.; Hübner, N.; Bauer, J.; Braun, M.; Schwarzwälder, A.; Segerer, J.; et al. Differential gene expression profile and altered cytokine secretion of thyroid cancer cells in space. FASEB J. 2014, 28, 813-835. [CrossRef] 
9. Tan, X.; Xu, A.; Zhao, T.; Zhao, Q.; Zhang, J.; Fan, C.; Deng, Y.; Freywald, A.; Genth, H.; Xiang, J. Simulated microgravity inhibits cell focal adhesions leading to reduced melanoma cell proliferation and metastasis via FAK/RhoA-regulated mTORC1 and AMPK pathways. Sci. Rep. 2018, 8, 3769. [CrossRef]

10. Lu, D.Y.; Sun, S.J.; Zhang, F.; Luo, C.H.; Zheng, L.; Wu, Y.; Li, N.; Zhang, C.; Wang, C.Z.; Chen, Q.; et al. Microgravity-induced hepatogenic differentiation of rBMSCs on board the SJ-10 satellite. FASEB J. 2019, 33, 4273-4286. [CrossRef]

11. Nassef, M.Z.; Kopp, S.; Wehland, M.; Melnik, D.; Sahana, J.; Krüger, M.; Corydon, T.J.; Oltmann, H.; Schmitz, B.; Schütte, A.; et al. Real microgravity influences the cytoskeleton and focal adhesions in human breast cancer cells. Int. J. Mol. Sci. 2019, 20, 3156. [CrossRef]

12. Zhang, S.; Liu, P.; Chen, L.; Wang, Y.; Wang, Z.; Zhang, B. The effects of spheroid formation of adipose-derived stem cells in a microgravity bioreactor on stemness properties and therapeutic potential. Biomaterials 2015, 41, 15-25. [CrossRef] [PubMed]

13. Buravkova, L.B.; Rudimov, E.G.; Andreeva, E.R.; Grigoriev, A.I. The ICAM-1 expression level determines the susceptibility of human endothelial cells to simulated microgravity. J. Cell Biochem. 2018, 119, 2875-2885. [CrossRef] [PubMed]

14. Nguon, K.; Li, G.-H.; Sajdel-Sulkowska, E.M. CNS development under altered gravity: Cerebellar glial and neuronal protein expression in rat neonates exposed to hypergravity. Adv. Space Res. 2004, 33, 1375-1380. [CrossRef] [PubMed]

15. Dittrich, A.; Grimm, D.; Sahana, J.; Bauer, J.; Krüger, M.; Infanger, M.; Magnusson, N.E. Key proteins involved in spheroid formation and angiogenesis in endothelial cells after long-Term exposure to simulated microgravity. Cell Physiol. Biochem. 2018, 45, 429-445. [CrossRef]

16. Ebnerasuly, F.; Hajebrahimi, Z.; Tabaie, S.M.; Darbouy, M. Simulated microgravity condition alters the gene expression of some ECM and adhesion molecules in adipose derived stem cells. Int. J. Mol. Cell Med. 2018, 7, 146-157.

17. Li, Y.; Gao, X.; Ling, S.; Zhong, G.; Sun, W.; Liu, C.; Li, J.; Song, J.; Zhao, D.; Jin, X.; et al. Knockdown of CD44 inhibits the alteration of osteoclast function induced by simulated microgravity. Acta Astronaut. 2019. [CrossRef]

18. Goodison, S.; Urquidi, V.; Tarin, D. CD44 cell adhesion molecules. J. Clin. Pathol. Mol. Pathol. 1999, 52, 189-196. [CrossRef]

19. Katayama, Y.; Hidalgo, A.; Chang, J.; Peired, A.; Frenette, P.S. CD44 is a physiological E-selectin ligand on neutrophils. J. Exp. Med. 2005, 201, 1183-1189. [CrossRef]

20. Bauer, J.; Wehland, M.; Infanger, M.; Grimm, D.; Gombocz, E. Semantic analysis of posttranslational modification of proteins accumulated in thyroid cancer cells exposed to simulated microgravity. Int. J. Mol. Sci. 2018, 19, 2257. [CrossRef]

21. Respress, J.L.; Gershovich, P.M.; Wang, T.; Reynolds, J.O.; Skapura, D.G.; Sutton, J.P.; Miyake, C.Y.; Wehrens, X.H.T. Long-term simulated microgravity causes cardiac RyR2 phosphorylation and arrhythmias in mice. Int. J. Cardiol. 2014, 176, 994-1000. [CrossRef] [PubMed]

22. Bettis, T.; Kim, B.J.; Hamrick, M.W. Impact of muscle atrophy on bone metabolism and bone strength: Implications for muscle-bone crosstalk with aging and disuse. Osteoporosis Int. 2018, 29, 1713-1720. [CrossRef] [PubMed]

23. Zhang, P.; Li, W.; Liu, H.; Li, J.; Wang, J.; Li, Y.; Chen, X.; Yang, Z.; Fan, M. Dystrophin involved in the susceptibility of slow muscles to hindlimb unloading via concomitant activation of TGF- $\beta 1 / \mathrm{Smad} 3$ signaling and ubiquitin-proteasome degradation in mice. Cell Biochem. Biophys. 2014, 70, 1057-1067. [CrossRef] [PubMed]

24. Bauer, J.; Wehland, M.; Pietsch, J.; Sickmann, A.; Weber, G.; Grimm, D. Annotated Gene and Proteome Data Support Recognition of Interconnections Between the Results of Different Experiments in Space Research. Microgravity Sci. Technol. 2016, 28, 357-365. [CrossRef]

25. Zhao, T.; Li, R.; Tan, X.; Zhang, J.; Fan, C.; Zhao, Q.; Deng, Y.; Xu, A.; Lukong, K.E.; Genth, H.; et al. Simulated microgravity reduces focal adhesions and alters cytoskeleton and nuclear positioning leading to enhanced apoptosis via suppressing FAK/Rhoa-mediated mTORC1/NF-kB and ERK1/2 pathways. Int. J. Mol. Sci. 2018, 19, 1994. [CrossRef] 
26. Kopp, S.; Kruger, M.; Bauer, J.; Wehland, M.; Corydon, T.J.; Sahana, J.; Nassef, M.Z.; Melnik, D.; Bauer, T.J.; Schulz, H.; et al. Microgravity affects thyroid cancer cells during the texus-53 mission stronger than hypergravity. Int. J. Mol. Sci. 2018, 19, 4001. [CrossRef]

27. Ohtsubo, K.; Marth, J.D. Glycosylation in Cellular Mechanisms of Health and Disease. Cell 2006, 126, 855-867. [CrossRef]

28. Lamblin, G.; Degroote, S.; Perini, J.-M.; Delmotte, P.; Scharfman, A.; Davril, M.; Lo-Guidice, J.-M.; Houdret, N.; Dumur, V.; Klein, A.; et al. Human airway mucin glycosylation: A combinatory of carbohydrate determinants which vary in cystic fibrosis. Glycoconjugate J. 2001, 18, 661-684. [CrossRef]

29. Morelle, W.; Michalski, J.-C. Analysis of protein glycosylation by mass spectrometry. Nat. Protocols 2007, 2, 1585-1602. [CrossRef]

30. Mehrishi, J.N.; Bauer, J. Electrophoresis of cells and the biological relevance of surface charge. Electrophoresis 2002, 23, 1984-1994. [CrossRef]

31. Du, J.; Hong, S.; Dong, L.; Cheng, B.; Lin, L.; Zhao, B.; Chen, Y.-G.; Chen, X. Dynamic sialylation in transforming growth factor- $\beta$ (TGF- $\beta$ )-induced epithelial to mesenchymal transition. J. Biol. Chem. 2015, 290, 12000-12013. [CrossRef] [PubMed]

32. Wang, B.; Brand-Miller, J. The role and potential of sialic acid in human nutrition. Eur. J. Clin. Nutr. 2013, 57, 1351-1369. [CrossRef]

33. Seaman, G.V.F. Electrochemical features of platelet interactions. Thrombosis Res. 1976, 8 (Suppl. 2), 235-246. [CrossRef]

34. Rodrigues, E.; Macauley, M.S. Hypersialylation in cancer: Modulation of inflammation and therapeutic opportunities. Cancers 2018, 10, 207. [CrossRef] [PubMed]

35. Cotton, T.R.; Joseph, D.D.A.; Jiao, W.; Parker, E.J. Probing the determinants of phosphorylated sugar-substrate binding for human sialic acid synthase. Biochim. Biophys. Acta Proteins Proteom. 2014, 1844, 2257-2264. [CrossRef] [PubMed]

36. Nishihara, S. Solute carrier family 35 (CMP-sialic acid transporter), member A1 (SLC35A1). In Handbook of Glycosyltransferases and Related Genes, 2nd ed.; Springer: Berlin/Heidelberg, Germany, 2014; pp. 1369-1377.

37. Bhide, G.P.; Colley, K.J. Sialylation of N-glycans: Mechanism, cellular compartmentalization and function. Histochem. Cell Biol. 2017, 147, 149-174. [CrossRef] [PubMed]

38. Bonten, E.; Van Der Spoel, A.; Fornerod, M.; Grosveld, G.; D’Azzo, A. Characterization of human lysosomal neuraminidase defines the molecular basis of the metabolic storage disorder sialidosis. Genes Dev. 1996, 10, 3156-3169. [CrossRef]

39. Monti, E.; Bassi, M.T.; Bresciani, R.; Civini, S.; Croci, G.L.; Papini, N.; Riboni, M.; Zanchetti, G.; Ballabio, A.; Preti, A.; et al. Molecular cloning and characterization of NEU4, the fourth member of the human sialidase gene family. Genomic 2004, 83, 445-453. [CrossRef]

40. Vajaria, B.N.; Patel, P.S. Glycosylation: A hallmark of cancer? Glycoconj. J. 2017, 34, 147-156. [CrossRef]

41. Kelm, S.; Schauer, R. Sialic acids in molecular and cellular interactions. Int. Rev. Cytol. 1997, 175, 137-240.

42. Joshi, L.; Shuler, M.L.; Wood, H.A. Production of a sialylated N-linked glycoprotein in insect cells. Biotechnol. Progress 2001, 17, 822-827. [CrossRef]

43. Gombocz, E.A.; Stanley, R.A.; Rockey, C.; Nishimura, T. Data Integration Framework for Discovery and Validation: Smart Merging of Experimental and Public Data Across Ontologies and Taxonomies. Available online: https:/de.slideshare.net/crockey/data-integration-framework-for-discoveryand-validation (accessed on 1 March 2020).

44. Stanley, R.A.; Gombocz, E.A. System, Method, Software Architecture, and Business Model for Intellegent Object Based Information Platform. U.S. Patent 7,702,639, 2010.

45. Bauer, T.J.; Gombocz, E.; Krüger, M.; Sahana, J.; Corydon, T.J.; Bauer, J.; Infanger, M.; Grimm, D. Augmenting cancer cell proteomics with cellular images-A semantic approach to understand focal adhesion. J. Biomed. Inf. 2019, 100, 103320. [CrossRef] [PubMed]

46. Deman, J.J.; van Larebeke, N.A.; Bruyneel, E.A.; Bracke, M.E.; Vermeulen, S.J.; Vennekens, K.M.; Mareel, M.M. Removal of sialic acid from the surface of human MCF-7 mammary cancer cells abolishes E-cadherin-dependent cell-cell adhesion in an aggregation assay. In Vitro Cell Dev. Biol. Anim. 1995, 31, 633-639. [CrossRef] [PubMed] 
47. Steelant, W.F.A.; Recchi, M.-A.; Noë, V.T.; Boilly-Marer, Y.; Bruyneel, E.A.; Verbert, A.; Mareel, M.M.; Delannoy, P. Sialylation of E-cadherin does not change the spontaneous or ET-18-OMe-mediated aggregation of MCF-7 human breast cancer cells. Clin. Exp. Metastasis 1999, 17, 245-253. [CrossRef] [PubMed]

48. Bassagañas, S.; Carvalho, S.; Dias, A.M.; Pérez-Garay, M.; Ortiz, M.R.; Figueras, J.; Reis, C.A.; Pinho, S.S.; Peracaula, R. Pancreatic cancer cell glycosylation regulates cell adhesion and invasion through the modulation of $\alpha 2 \beta 1$ integrin and E-cadherin function. PLoS ONE 2014, 9, e98595. [CrossRef] [PubMed]

49. Li, J.; Cheng, L.; Wang, L.-J.; Liu, H.-C.; Li, L.; Wang, X.-L.; Geng, M.-Y. Cell surface sialic acid inhibits Cx43 gap junction functions in constructed Hela cancer cells involving in sialylated N-cadherin. Mol. Cell Biochem. 2010, 344, 241-251. [CrossRef]

50. Ciołczyk-Wierzbicka, D.; Amoresano, A.; Casbarra, A.; Hoja-Łukowicz, D.; Lityńska, A.; Laidler, P. The structure of the oligosaccharides of N-cadherin from human melanoma cell lines. Glycoconjugate J. 2003, 20, 483-492. [CrossRef]

51. Przybyło, M.; Hoja-Lukowicz, D.; Lityńska, A.; Laidler, P. Different glycosylation of cadherins from human bladder non-malignant and cancer cell lines. Cancer Cell Int. 2001, 2, 5.

52. Geyer, H.; Geyer, R.; Odenthal-Schnittler, M.; Schnittler, H.J. Characterization of human vascular endothelial cadherin glycans. Glycobiology 1999, 9, 915-925. [CrossRef]

53. Deng, X.; Zhang, J.; Liu, Y.; Chen, L.; Yu, C. TNF- $\alpha$ regulates the proteolytic degradation of ST6Gal-1 and endothelial cell-cell junctions through upregulating expression of BACE1. Sci. Rep. 2017, 7, 40256. [CrossRef]

54. Krüger, M.; Pietsch, J.; Bauer, J.; Kopp, S.; Carvalho, D.T.O.; Baatout, S.; Moreels, M.; Melnik, D.; Wehland, M.; Egli, M.; et al. Growth of endothelial cells in space and in simulated microgravity-A comparison on the secretory level. Cell Physiol. Biochem. 2019, 52, 1039-1060.

55. Minami, A.; Shimono, Y.; Mizutani, K.; Nobutani, K.; Momose, K.; Azuma, T.; Takai, Y. Reduction of the ST6 $\beta$-Galactosamide $\alpha$-2,6-sialyltransferase 1 (ST6GAL1)-catalyzed sialylation of nectin-like molecule 2/cell adhesion molecule 1 and enhancement of ErbB2/ErbB3 signaling by microRNA-199a. J. Biol. Chem. 2013, 288, 11845-11853. [CrossRef] [PubMed]

56. Scott, D.W.; Tolbert, C.E.; Graham, D.M.; Wittchen, E.; Bear, J.E.; Burridge, K. N-glycosylation controls the function of junctional adhesion molecule-A. Mol. Biol. Cell 2015, 26, 3205-3214. [CrossRef]

57. Hou, S.; Hang, Q.; Isaji, T.; Lu, J.; Fukuda, T.; Gu, J. Importance of membrane-proximal N-glycosylation on integrin $\beta 1$ in its activation and complex formation. FASEB J. 2016, 30, 4120-4131. [CrossRef] [PubMed]

58. Liu, Y.; Pan, D.; Bellis, S.L.; Song, Y. Effect of altered glycosylation on the structure of the I-like domain of $\beta 1$ integrin: A molecular dynamics study. Proteins Struct. Funct. Genet. 2008, 73, 989-1000. [CrossRef] [PubMed]

59. Semel, A.C.; Seales, E.C.; Singhal, A.; Eklund, E.A.; Colley, K.J.; Bellis, S.L. Hyposialylation of integrins stimulates the activity of myeloid fibronectin receptors. J. Biol. Chem. 2002, 277, 32830-32836. [CrossRef]

60. Shaikh, F.M.; Seales, E.C.; Clem, W.C.; Hennessy, K.M.; Zhuo, Y.; Bellis, S.L. Tumor cell migration and invasion are regulated by expression of variant integrin glycoforms. Exp. Cell Res. 2008, 314, 2941-2950. [CrossRef]

61. Lee, M.; Park, J.J.; Lee, Y.S. Adhesion of ST6Gal I-mediated human colon cancer cells to fibronectin contributes to cell survival by integrin $\beta 1$-mediated paxillin and AKT activation. Oncol. Rep. 2010, 23, 757-761.

62. Jurado, G.A.; Brunson, B.A.; Wakefield, J.K.; Frost, A.R.; Bellis, S.L. Hypersialylation of $\beta 1$ integrins, observed in colon adenocarcinoma, may contribute to cancer progression by up-regulating cell motility. Cancer Res. 2005, 65, 4645-4652.

63. Zhuo, Y.; Chammas, R.; Bellis, S.L. Sialylation of $\beta 1$ integrins blocks cell adhesion to galectin-3 and protects cells against galectin-3-induced apoptosis. J. Biol. Chem. 2008, 283, 22177-22185. [CrossRef]

64. Chen, J.-Y.; Tang, Y.-A.; Huang, S.-M.; Juan, H.-F.; Wu, L.-W.; Sun, Y.-C.; Wang, S.-C.; Wu, K.-W.; Balraj, G.; Chang, T.T.; et al. A novel sialyltransferase inhibitor suppresses FAK/paxillin signaling and cancer angiogenesis and metastasis pathways. Cancer Res. 2011, 71, 473-483. [CrossRef] [PubMed]

65. Chiang, C.-H.; Wang, C.-H.; Chang, H.-C.; More, S.V.; Li, W.-S.; Hung, W.-C. A novel sialyltransferase inhibitor AL10 suppresses invasion and metastasis of lung cancer cells by inhibiting integrin-mediated signaling. J. Cell Physiol. 2010, 223, 492-499. [CrossRef] [PubMed]

66. Yuan, Y.; Wu, L.; Shen, S.; Wu, S.; Burdick, M.M. Effect of alpha 2,6 sialylation on integrin-mediated adhesion of breast cancer cells to fibronectin and collagen IV. Life Sci. 2016, 149, 138-145. [CrossRef] [PubMed]

67. Van Slambrouck, S.; Groux-Degroote, S.; Krzewinski-Recchi, M.A.; Cazet, A.; Delannoy, P.; Steelant, W.F.A. Carbohydrate-to-carbohydrate interactions between $\alpha 2,3$-linked sialic acids on $\alpha 2$ integrin subunits and 
asialo-GM1 underlie the bone metastatic behaviour of LNCAP-derivative C4-2B prostate cancer cells. Biosci. Rep. 2014, 34, e00138. [CrossRef] [PubMed]

68. Ethier, M.; Krokhin, O.; Ens, W.; Standing, K.G.; Wilkins, J.A.; Perreault, H. Global and site-specific detection of human integrin $\alpha 5 \beta 1$ glycosylation using tandem mass spectrometry and the StrOligo algorithm. Rapid Commun. Mass Spectrom. 2005, 19, 721-727. [CrossRef]

69. Kolasińska, E.; Janik, M.E.; Lityńska, A.; Przybyło, M. Contribution of sialic acids to integrin $\alpha 5 \beta 1$ functioning in melanoma cells. Adv. Med. Sci. 2019, 64, 267-273. [CrossRef]

70. Sanchez-Ruderisch, H.; Detjen, K.M.; Welzel, M.; André, S.; Fischer, C.; Gabius, H.-J.; Rosewicz, S. Galectin-1 sensitizes carcinoma cells to anoikis via the fibronectin receptor $\alpha 5 \beta 1$-integrin. Cell Death Differ. 2011, 18, 806-816. [CrossRef]

71. Pan, D.; Song, Y. Role of altered sialylation of the i-like domain of $\beta 1$ integrin in the binding of fibronectin to $\beta 1$ integrin: Thermodynamics and conformational analyses. Biophys. J. 2010, 99, 208-217. [CrossRef]

72. Isaji, T.; Sato, Y.; Fukuda, T.; Gu, J. N-glycosylation of the I-like domain of $\beta 1$ integrin is essential for $\beta 1$ integrin expression and biological function. Identification of the minimal N-glycosylation requirement for

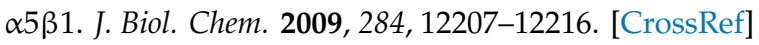

73. Nadanaka, S.; Sato, C.; Kitajima, K.; Katagiri, K.; Irie, S.; Yamagata, T. Occurrence of Oligosialic Acids on Integrin $\alpha 5 \beta 1$-Subunit and Their Involvement in Cell Adhesion to Fibronectin. J. Biol. Chem. 2001, 276, 33657-33664. [CrossRef]

74. Pocheć, E.; Lityńska, A.; Bubka, M.; Amoresano, A.; Casbarra, A. Characterization of the oligosaccharide component of alpha(3)beta(1) integrin from human bladder carcinoma cell line T24 and its role in adhesion and migration. Eur. J. Cell Biol. 2006, 85, 47-57. [CrossRef]

75. Huang, Z.; Miao, X.; Patarroyo, M.; Nilsson, G.P.; Pernow, J.; Li, N. Tetraspanin CD151 and integrin $\alpha 6 \beta 1$ mediate platelet-enhanced endothelial colony forming cell angiogenesis. J. Thrombosis Haemostasis 2016, 14, 606-618. [CrossRef] [PubMed]

76. Uemura, T.; Shiozaki, K.; Yamaguchi, K.; Miyazaki, S.; Satomi, S.; Kato, K.; Sakuraba, H.; Miyagi, T. Contribution of sialidase NEU1 to suppression of metastasis of human colon cancer cells through desialylation of integrin $\beta 4$. Oncogene 2009, 28, 1218-1229. [CrossRef] [PubMed]

77. Pocheć, E.; Bubka, M.; Rydlewska, M.; Janik, M.; Pokrywka, M.; Lityńska, A. Aberrant glycosylation $\alpha$ V $\beta 3$ integrin is associated with melanoma progression. Anticancer Res. 2015, 35, 2093-2103. [PubMed]

78. Imamaki, R.; Ogawa, K.; Kizuka, Y.; Komi, Y.; Kojima, S.; Kotani, N.; Honke, K.; Honda, T.; Taniguchi, N.; Kitazume, S. Glycosylation controls cooperative PECAM-VEGFR2- $\beta 3$ integrin functions at the endothelial surface for tumor angiogenesis. Oncogene 2018, 37, 4287-4299. [CrossRef]

79. Zhou, L.; Zhang, S.; Zou, X.; Lu, J.; Yang, X.; Xu, Z.; Shan, A.; Jia, W.; Liu, F.; Yan, X.; et al. The $\beta$-galactoside $\alpha 2,6$-sialyltranferase I (ST6GAL1) inhibits the colorectal cancer metastasis by stabilizing intercellular adhesion molecule-I via sialylation. Cancer Manag. Res. 2019, 11, 6185-6199. [CrossRef]

80. Suzuki, O.; Abe, M.; Hashimoto, Y. Sialylation by $\beta$-galactoside $\alpha$-2,6-sialyltransferase and N-glycans regulate cell adhesion and invasion in human anaplastic large cell lymphoma. Int. J. Oncol. 2015, 46, 973-980. [CrossRef]

81. Rutishauser, U. Polysialic acid at the cell surface: Biophysics in service of cell interactions and tissue plasticity. J. Cell Biochem. 1998, 70, 304-312. [CrossRef]

82. Hoja-Łukowicz, D.; Przybyło, M.; Duda, M.; Pocheć, E.; Bubka, M. On the trail of the glycan codes stored in cancer-related cell adhesion proteins. Biochim. Biophys. Acta Gen. Subj. 2017, 1861, 3237-3257. [CrossRef] [PubMed]

83. Moller, C.J.; Christgau, S.; Williamson, M.R.; Madson, O.D.; Zhango, N.; Bock, E.; Baekkeskov, S. Differential expression of neural cell-adhesion molecule and cadherins in pancreatic-islets, glucagonomas and insulinomas. Mol. Endocrinol. 1992, 6, 1332-1342.

84. Colley, K.J.; Kitajima, K.; Sato, C. Polysialic acid: Biosynthesis, novel functions and applications. Critical Rev. Biochem. Mol. Biol. 2014, 49, 498-532. [CrossRef] [PubMed]

85. Hane, M.; Matsuoka, S.; Ono, S.; Miyata, S.; Kitajima, K.; Sato, C. Protective effects of polysialic acid on proteolytic cleavage of FGF2 and proBDNF/BDNF. Glycobiology 2015, 25, 1112-1124. [CrossRef] [PubMed]

86. Seifert, A.; Glanz, D.; Glaubitz, N.; Horstkorte, R.; Bork, K. Polysialylation of the neural cell adhesion molecule: Interfering with polysialylation and migration in neuroblastoma cells. Arch. Biochem. Biophys. 2012, 524, 56-63. [CrossRef] [PubMed] 
87. Gong, L.; Zhou, X.; Yang, J.; Jiang, Y.; Yang, H. Effects of the regulation of polysialyltransferase ST8SiaII on the invasiveness and metastasis of small cell lung cancer cells. Oncol. Rep. 2017, 37, 131-138. [CrossRef]

88. Storms, S.D.; Jensen, J.J.; Yaghmai, D.; Murray, B.A. Multiple mechanisms of N2A and CHO cell adhesion to NCAM purified from chick embryonic brain and retina. Exp. Cell Res. 1994, 214, 100-112. [CrossRef]

89. Guan, F.; Wang, X.; He, F. Promotion of cell migration by neural cell adhesion molecule (NCAM) is enhanced by PSA in a polysialyltransferase-specific manner. PLOS ONE 2015, 10, e0124237. [CrossRef]

90. Schreiber, S.C.; Giehl, K.; Kastilan, C.; Hasel, C.; Mühlenhoff, M.; Adler, G.; Wedlich, D.; Menke, A. Polysialylated NCAM Represses E-Cadherin-Mediated Cell-Cell Adhesion in Pancreatic Tumor Cells. Gastroenterology 2008, 134, 1555-1566. [CrossRef]

91. Chen, Y.; Ding, L.; Song, W.; Yang, M.; Ju, H. Liberation of Protein-Specific Glycosylation Information for Glycan Analysis by Exonuclease III-Aided Recycling Hybridization. Anal. Chem. 2016, 88, 2923-2928. [CrossRef]

92. Lee, C.; Liu, A.; Miranda-Ribera, A.; Hyun, S.W.; Lillehoj, E.P.; Cross, A.S.; Passaniti, A.; Grimm, P.R.; Kim, B.Y.; Welling, P.A.; et al. NEU1 sialidase regulates the sialylation state of CD31 and disrupts CD31-driven capillary-like tube formation in human lung microvascular endothelia. J. Biol. Chem. 2014, 289, 9121-9135. [CrossRef]

93. Kitazume, S.; Imamaki, R.; Ogawa, K.; Komi, Y.; Futakawa, S.; Kojima, S.; Hashimoto, Y.; Marth, J.D.; Paulson, J.C.; Taniguchi, N. $\alpha 2,6$-sialic acid on Platelet Endothelial Cell Adhesion Molecule (PECAM) regulates its homophilic interactions and downstream antiapoptotic signaling. J. Biol. Chem. 2010, 285, 6515-6521. [CrossRef]

94. Lertkiatmongkol, P.; Paddock, C.; Newman, D.K.; Zhu, J.; Thomas, M.J.; Newman, P.J. The role of sialylated glycans in human platelet endothelial cell adhesion molecule 1 (PECAM-1)-mediated trans homophilic interactions and endothelial cell barrier function. J. Biol. Chem. 2016, 291, 26216-26225. [CrossRef] [PubMed]

95. Hyun, S.W.; Liu, A.; Liu, Z.; Lillehoj, E.P.; Madri, J.A.; Reynolds, A.B.; Goldblum, S.E. As human lung microvascular endothelia achieve confluence, src family kinases are activated, and tyrosine-phosphorylated p120 catenin physically couples NEU1 sialidase to CD31. Cell Signal. 2017, 35, 1-15. [CrossRef] [PubMed]

96. Guvench, O. Revealing the mechanisms of protein disorder and N-glycosylation in CD44-hyaluronan binding using molecular simulation. Front. Immunol. 2015, 6, 305. [CrossRef] [PubMed]

97. Faller, C.E.; Guvench, O. Terminal sialic acids on CD44 N-glycans can block hyaluronan binding by forming competing intramolecular contacts with arginine sidechains. Proteins Struct. Funct. Bioinf. 2014, 82, 3079-3089. [CrossRef]

98. Katoh, S.; Miyagi, T.; Taniguchi, H.; Matsubara, Y.I.; Kadota, J.I.; Tominaga, A.; Kincade, P.W.; Matsukura, S.; Kohno, S. Cutting edge: An inducible sialidase regulates the hyaluronic acid binding ability of CD44-bearing human monocytes. J. Immunol. 1999, 162, 5058-5061.

99. Isozaki, H.; Ohyama, T.; Mabuchi, H. Expression of cell adhesion molecule CD44 and sialyl Lewis A in gastric carcinoma and colorectal carcinoma in association with hepatic metastasis. Int. J. Oncol. 1998, 13, 935-939. [CrossRef]

100. Matsubara, Y.; Katoh, S.; Taniguchi, H.; Oka, M.; Kadota, J.; Kohno, S. Expression of CD44 variants in lung cancer and its relationship to hyaluronan binding. J. Int. Med. Res. 2000, 28, 78-90. [CrossRef]

101. Riwaldt, S.; Bauer, J.; Wehland, M.; Slumstrup, L.; Kopp, S.; Warnke, E.; Dittrich, A.; Magnusson, N.E.; Pietsch, J.; Corydon, T.J.; et al. Pathways regulating spheroid formation of human follicular thyroid cancer cells under simulated microgravity conditions: A genetic approach. Int. J. Mol. Sci. 2016, 17, 528. [CrossRef]

102. Kopp, S.; Slumstrup, L.; Corydon, T.J.; Sahana, J.; Aleshcheva, G.; Islam, T.; Magnusson, N.E.; Wehland, M.; Bauer, J.; Infanger, M.; et al. Identifications of novel mechanisms in breast cancer cells involving duct-like multicellular spheroid formation after exposure to the random positioning machine. Sci. Rep. 2016, 6, 26887. [CrossRef]

103. Bellis, S.L. Variant glycosylation: An underappreciated regulatory mechanism for $\beta 1$ integrins. Biochim. Biophys. Acta Biomembr. 2004, 1663, 52-60. [CrossRef]

104. Vajaria, B.N.; Patel, K.R.; Begum, R.; Patel, P.S. Sialylation: An Avenue to Target Cancer Cells. Pathol. Oncol. Res. 2016, 22, 443-447. [CrossRef]

105. Sawada, T.; Ho, J.J.L.; Sagabe, T.; Yoon, W.H.; Chung, Y.S.; Sowa, M.; Kim, Y.S. Biphasic Effect of Cell Surface Sialic Acids on Pancreatic Cancer Cell Adhesiveness. Biochem. Biophys. Res. Commun. 1993, 195, 1096-1103. [CrossRef] 
106. Miyagi, T.; Takahashi, K.; Hata, K.; Shiozaki, K.; Yamaguchi, K. Sialidase significance for cancer progression. Glycoconj. J. 2012, 29, 567-577. [CrossRef]

107. Bresalier, R.S.; Ho, S.B.; Schoeppner, H.L.; Kim, Y.S.; Sleisenger, M.H.; Brodt, P.; Byrd, J.C. Enhanced sialylation of mucin-associated carbohydrate structures in human colon cancer metastasis. Gastroenterology 1996, 110, 1354-1367. [CrossRef] [PubMed]

108. Yu, S.H.; Zhao, P.; Sun, T.; Gao, Z.; Moremen, K.W.; Boons, G.J.; Wells, L.; Steet, R. Selective exo-enzymatic labeling detects increased cell surface sialoglycoprotein expression upon megakaryocytic differentiation. J. Biol. Chem. 2016, 291, 3982-3989. [CrossRef] [PubMed]

109. Döring, Y.; Noels, H.; Mandl, M.; Kramp, B.; Neideck, C.; Lievens, D.; Drechsler, M.; Megens, R.T.A.; Tilstam, P.V.; Langer, M.; et al. Deficiency of the sialyltransferase St3Gal4 reduces Ccl5-mediated myeloid cell recruitment and arrest. Circ. Res. 2014, 114, 976-981. [CrossRef] [PubMed]

110. Hedlund, M.; Ng, E.; Varki, A.; Varki, N.M. $\alpha 2-6$-linked sialic acids on N-glycans modulate carcinoma differentiation in vivo. Cancer Res. 2008, 68, 388-394. [CrossRef] [PubMed]

111. Han, Y.; Liu, Y.; Fu, X.; Zhang, Q.; Huang, H.; Zhang, C.; Li, W.; Zhang, J. miR-9 inhibits the metastatic ability of hepatocellular carcinoma via targeting beta galactoside alpha-2,6-sialyltransferase 1. J. Physiol. Biochem. 2018, 74, 491-501. [CrossRef]

112. Kaburagi, T.; Kizuka, Y.; Kitazume, S.; Taniguchi, N. The inhibitory role of $\alpha 2,6$-sialylation in adipogenesis. J. Biol. Chem. 2017, 292, 2278-2286. [CrossRef]

113. Kroes, R.A.; Moskal, J.R. The role of DNA methylation in ST6Gal1 expression in gliomas. Glycobiology 2016, 26, 1271-1283. [CrossRef]

114. Man Ip, C.K.; Yung, S.; Chan, T.M.; Tsao, S.W.; Wong, A.S.T. p70 S6 kinase drives ovarian cancer metastasis through multicellular spheroid-peritoneum interaction and P-cadherin/ $\beta 1$ integrin signaling activation. Oncotarget 2014, 5, 9133-9149.

115. Lu, J.; Isaji, T.; Im, S.; Fukuda, T.; Hashii, N.; Takakura, D.; Kawasaki, N.; Gu, J. $\beta$-Galactoside $\alpha 2,6$-sialyltranferase 1 promotes transforming growth factor- $\beta$-mediated epithelial-mesenchymal transition. J. Biol. Chem. 2014, 289, 34627-34641. [CrossRef] [PubMed]

116. Lee, M.; Lee, H.-J.; Bae, S.; Lee, Y.-S. Protein sialylation by sialyltransferase involves radiation resistance. Mol. Cancer Res. 2008, 6, 1316-1325. [CrossRef] [PubMed]

117. Pshezhetsky, A.V.; Ashmarina, M. Keeping it trim: Roles of neuraminidases in CNS function. Glycoconjugate J. 2018, 35, 375-386. [CrossRef]

118. Glanz, V.Y.; Myasoedova, V.A.; Grechko, A.V.; Orekhov, A.N. Sialidase activity in human pathologies. Eur. J. Pharmacol. 2019, 842, 345-350. [CrossRef]

119. Tringali, C.; Lupo, B.; Cirillo, F.; Papini, N.; Anastasia, L.; Lamorte, G.; Colombi, P.; Bresciani, R.; Monti, E.; Tettamanti, G.; et al. Silencing of membrane-associated sialidase Neu3 diminishes apoptosis resistance and triggers megakaryocytic differentiation of chronic myeloid leukemic cells K562 through the increase of ganglioside GM3. Cell Death Differ. 2009, 16, 164-174. [CrossRef]

120. Colomb, F.; Krzewinski-Recchi, M.-A.; Steenackers, A.; Vincent, A.; Harduin-Lepers, A.; Delannoy, P.; Groux-Degroote, S. TNF up-regulates ST3GAL4 and sialyl-Lewisx expression in lung epithelial cells through an intronic ATF2-responsive element. Biochem. J. 2017, 474, 65-78. [CrossRef]

121. Wu, X.; Zhao, J.; Ruan, Y.; Sun, L.; Xu, C.; Jiang, H. Sialyltransferase ST3GAL1 promotes cell migration, invasion, and TGF- $\beta 1$-induced EMT and confers paclitaxel resistance in ovarian cancer. Cell Death Disease 2018, 9, 1102. [CrossRef]

122. Dalziel, M.; Dall'Olio, F.; Mungul, A.; Piller, V.; Piller, F. Ras oncogene induces $\beta$-galactoside $\alpha 2,6$-sialyltransferase (ST6Gal I) via a RalGEF-mediated signal to its housekeeping promoter. Eur. J. Biochem. 2004, 271, 3623-3634. [CrossRef]

123. Jia, L.; Luo, S.; Ren, X.; Li, Y.; Hu, J.; Liu, B.; Zhao, L.; Shan, Y.; Zhou, H. miR-182 and miR-135b Mediate the Tumorigenesis and Invasiveness of Colorectal Cancer Cells via Targeting ST6GALNAC2 and PI3K/AKT Pathway. Digest. Diseases Sci. 2017, 62, 3447-3459. [CrossRef]

124. Li, Y.L.; Wu, G.Z.; Zeng, L.; Dawe, G.S.; Sun, L.; Loers, G.; Tilling, T.; Cui, S.; Schachner, M.; Xiao, Z.C. Cell surface sialylation and fucosylation are regulated by the cell recognition molecule L1 via PLC $\gamma$ and cooperate to modulate embryonic stem cell survival and proliferation. FEBS Lett. 2009, 583, 703-710. [CrossRef] [PubMed] 
125. Meng, Q.; Ren, C.; Wang, L.; Zhao, Y.; Wang, S. Knockdown of ST6Gal-I inhibits the growth and invasion of osteosarcoma MG-63 cells. Biomed. Pharmacother. 2015, 72, 172-178. [CrossRef] [PubMed]

126. Li, N.; Ren, A.; Wang, X.; Fan, X.; Zhao, Y.; Gao, G.F.; Cleary, P.; Wang, B. Influenza viral neuraminidase primes bacterial coinfection through TGF- $\beta$-Mediated expression of host cell receptors. Proc. Natl. Acad. Sci. USA 2015, 112, 238-243. [CrossRef]

127. Yu, S.; Fan, J.; Liu, L.; Zhang, L.; Wang, S.; Zhang, J. Caveolin-1 up-regulates integrin $\alpha 2,6$-sialylation to promote integrin $\alpha 5 \beta 1$-dependent hepatocarcinoma cell adhesion. FEBS Lett. 2013, 587, 782-787. [CrossRef] [PubMed]

128. Wang, Y.; Yamaguchi, K.; Wada, T.; Hata, K.; Zhao, X.; Fujimoto, T.; Miyagi, T.; Collins, B.M.; Davis, M.J.; Hancock, J.F.; et al. Structure-Based Reassessment of the Caveolin Signaling Model: Do Caveolae Regulate Signaling through Caveolin-Protein Interactions? Dev. Cell 2012, 23, 11-20.

129. Riwaldt, S.; Bauer, J.; Pietsch, J.; Braun, M.; Segerer, J.; Schwarzwälder, A.; Corydon, T.J.; Infanger, M.; Grimm, D. The importance of caveolin-1 as key-regulator of three-dimensional growth in thyroid cancer cells cultured under real and simulated microgravity conditions. Int. J. Mol. Sci. 2015, 16, 28296-28310. [CrossRef]

130. Riwaldt, S.; Pietsch, J.; Sickmann, A.; Bauer, J.; Braun, M.; Segerer, J.; Schwarzwälder, A.; Aleshcheva, G.; Corydon, T.J.; Infanger, M.; et al. Identification of proteins involved in inhibition of spheroid formation under microgravity. Proteomics 2015, 15, 2945-2952. [CrossRef]

131. Warnke, E.; Pietsch, J.; Wehland, M.; Bauer, J.; Infanger, M.; Görög, M.; Hemmersbach, R.; Braun, M.; Ma, X.; Sahana, J.; et al. Spheroid formation of human thyroid cancer cells under simulated microgravity: A possible role of CTGF and CAV1. Cell Commun. Signal. 2014, 12, 32. [CrossRef]

132. Slivinsky, G.G.; Hymer, W.C.; Bauer, J.; Morrison, D.R. Cellular electrophoretic mobility data: A first approach to a database. Electrophoresis 1997, 18, 1109-1119. [CrossRef]

133. Weber, G.; Grimm, D.; Bauer, J. Application of binary buffer systems to free flow cell electrophoresis. Electrophoresis 2000, 21, 325-328. [CrossRef]

134. Mehrishi, J.N. Action of Pronase and Neuraminidase on the Electrophoretic Mobility of Erythrocytes from Normal Cats and those with Spontaneous Tumours. Vox Sanguinis 1970, 18, 27-33. [CrossRef] [PubMed]

135. Bauer, J.; Cohly, H.H.P.; Sahana, J.; Grimm, D. Preparative enrichment of human tissue cells capable to change a site of growth in vitro or in vivo-Recent developments. Preparative Biochem. Biotechnol. 2018, 48, 954-960. [CrossRef] [PubMed]

136. Nagaraj, N.; Kulak, N.A.; Cox, J.; Neuhauser, N.; Mayr, K.; Hoerning, O.; Vorm, O.; Mann, M. System-wide perturbation analysis with nearly complete coverage of the yeast proteome by single-shot ultra HPLC runs on a bench top Orbitrap. Mol. Cell Proteom. 2012, 11, M111.013722. [CrossRef] [PubMed]

137. Rappsilber, J.; Mann, M.; Ishihama, Y. Protocol for micro-purification, enrichment, pre-fractionation and storage of peptides for proteomics using StageTips. Nat. Protoc. 2007, 2, 1896-1906. [CrossRef] [PubMed]

138. Cox, J.; Mann, M. MaxQuant enables high peptide identification rates, individualized p.p.b.-range mass accuracies and proteome-wide protein quantification. Nat. Biotechnol. 2008, 26, 1367-1372. [CrossRef] [PubMed]

139. Cox, J.; Hein, M.; Luber, C.A.; Paron, I.; Nagaraj, N.; Mann, M. Accurate proteome-wide label-free quantification by delayed normalization and maximal peptide ratio extraction, termed MaxLFQ. Mol. Cell Proteom. 2014, 13, 2513-2526. [CrossRef]

140. Pietsch, J.; Kussian, R.; Sickmann, A.; Bauer, J.; Weber, G.; Nissum, M.; Westphal, K.; Egli, M.; Grosse, J.; Schönberger, J.; et al. Application of free-flow IEF to identify protein candidates changing under microgravity conditions. Proteomics 2010, 10, 904-913. [CrossRef]

141. Hancock, W.S.; Wu, S.L.; Stanley, R.A.; Gombocz, E.A. Publishing large proteome datasets: Scientific policy meets emerging technologies. Trends Biotechnol. 2002, 20, S39-S44. [CrossRef]

142. Boutet, E.; Lieberherr, D.; Tognolli, M.; Schneider, M.; Bansal, D.; Bridge, A.J.; Poux, S.; Bougueleret, L.; Xenarios, I. UniProtKB/Swiss-Prot, the manually annotated section of the UniProt KnowledgeBase: How to use the entry view. Methods Mol. Biol. 2016, 1374, 23-54.

143. Lindberg, D.A. Internet access to the National Library of Medicine. Eff. Clin. Pract. 2000, 3, 256-260.

144. Garnham, R.; Scott, E.; Livermore, K.E.; Munkley, J. ST6GAL1: A key player in cancer. Oncol. Lett. 2019, 18, 983-989. [PubMed]

(C) 2020 by the authors. Licensee MDPI, Basel, Switzerland. This article is an open access article distributed under the terms and conditions of the Creative Commons Attribution (CC BY) license (http://creativecommons.org/licenses/by/4.0/). 